\title{
Assessing the Effect of Mycotoxin Combinations: Which Mathematical Model Is (the Most) Appropriate?
}

\author{
Domagoj Kifer $^{1}{ }^{(D}$, Daniela Jakšić ${ }^{2}$ and Maja Šegvić Klarić ${ }^{2, *}$ \\ 1 Department of Biophysics, Faculty of Pharmacy and Biochemistry, University of Zagreb, A. Kovačića 1, \\ Zagreb 10000, Croatia; dkifer@pharma.hr \\ 2 Department of Microbiology, Faculty of Pharmacy and Biochemistry, University of Zagreb, Schrottova 39, \\ Zagreb 10000, Croatia; djaksic@pharma.hr \\ * Correspondence: msegvic@pharma.hr; Tel.: +385-1-6394-493
}

Received: 8 January 2020; Accepted: 26 February 2020; Published: 29 February 2020

check for updates

\begin{abstract}
In the past decades, many studies have examined the nature of the interaction between mycotoxins in biological models classifying interaction effects as antagonisms, additive effects, or synergisms based on a comparison of the observed effect with the expected effect of combination. Among several described mathematical models, the arithmetic definition of additivity and factorial analysis of variance were the most commonly used in mycotoxicology. These models are incorrectly based on the assumption that mycotoxin dose-effect curves are linear. More appropriate mathematical models for assessing mycotoxin interactions include Bliss independence, Loewe's additivity law, combination index, and isobologram analysis, Chou-Talalays median-effect approach, response surface, code for the identification of synergism numerically efficient (CISNE) and MixLow method. However, it seems that neither model is ideal. This review discusses the advantages and disadvantages of these mathematical models.
\end{abstract}

Keywords: mycotoxin interaction; Loewe additivity; combination index; isobologram; Chou-Talalay method; MixLow

Key Contribution: Comments on methods for assessing mycotoxin combination effect.

\section{Introduction}

Mycotoxins are secondary metabolites mainly produced by fungi belonging to the genera of Aspergillus, Penicillium, or Fusarium [1]. Although the role of mycotoxins is not yet fully understood, it has been shown that mycotoxins form an integral part of microbial interactions in ecological niches where they protect fungi from competing or invading microbes (e.g., by antimicrobial activity and/or quorum sensing disruption) [2,3]. Throughout history, these fungal toxic metabolites have been recognized as harmful contaminants in crops, causing acute toxic, carcinogenic, mutagenic, teratogenic, immunotoxic, and oestrogenic effects in humans and animals [1,4]. From the public health point of view, the most important foodborne mycotoxins are aflatoxins (AFs), fumonisins (FBs), trichothecenes (including deoxynivalenol (DON) and T-2 and HT-2 toxins), ochratoxin A (OTA), patulin (PAT) and zearalenone (ZEN) and maximum levels have been set in European Union legislation to control these mycotoxin levels in food and feed [4,5]. Analytical methods based on the liquid chromatography tandem mass spectrometry (LC-MS/MS) have been developed for the simultaneous detection of multiple mycotoxins in foods which facilitated and enabled survey of their co-occurrence in various food matrices [6,7]. This methodology enabled the simultaneous detection of more than one hundred fungal metabolites including major mycotoxins as well as masked (e.g., DON-3-glucoside 
and ZEN-14 sulfate), modified mycotoxins (e.g., 15-acetyl-DON) and so called emerging mycotoxins (enniatins-ENN, beauvericin-BEA, and fusaproliferin-FUS and moniliformin-MON) [8-13]. The latter is defined as "mycotoxins, which are neither routinely determined, nor legislatively regulated; however, the evidence of their incidence is rapidly increasing" [13]. Recently, for the first time ever, reports were published on the multi-occurrence on major mycotoxins and their derivates as well as modified mycotoxins (such as DON-3-glucoside) and emerging mycotoxins in animal feeds and maize from Egypt. This study emphasized significant levels of $\mathrm{AFB}_{1}$ in this African region, but also suggested that low concentrations of the other detected mycotoxins should also be considered due to their unknown interactions [6]. As mycotoxins often co-occur in food and feed there is a possibility that, due to interactions between one or more mycotoxins, they can act harmfully, even if they are present at or below permitted concentrations (regulated mycotoxins) or are continuously present in low or high levels depending on the region (unregulated/emerging mycotoxins) [10-12]. Assunção et al. [5] underlined the priority of testing the most relevant mycotoxins mixtures taking into account human exposure assessments and the use of adequate mathematical approaches to evaluate interactions in experimental models. Kademi et al. [14] developed a mathematical model using a system of ordinary differential equations to describe the dynamics of AFs from plants (feeds) to animals, plants (plant foods) to humans, and animals to humans (carry-over effects) which showed that the entire dynamics depends on the numerical values of the threshold quantity defined as $R_{01}$ and $R_{02}$ (e.g., if $R_{01}<1$ and $\mathrm{R}_{02}<1$ then AF concentrations in animals and plants will not reach toxic limit and vice versa). This kind of mathematical modeling can be useful in controlling AFs and other mycotoxin toxicity limits by employing various control measures like biological control and/or decontamination technologies. In addition, mathematical modeling has been applied to predict fungal germination, growth, mycotoxin production, inactivation and also to study the response to environmental factors which can be useful in the prediction of mycotoxin food contamination $[15,16]$. Taken together, mathematical modeling could be very helpful in the prediction and estimation of mycotoxin impact on human and animal health as well as in controlling contamination below acceptable limits.

In vitro studies of mycotoxin interactions reflect mycotoxin occurrence and co-occurrence in food/feed. Among Aspergillus- and/or Penicillium-derived mycotoxins, $\mathrm{AFB}_{1}$, OTA, citrinin (CIT), PAT and penicillic acid (PA) have been the most studied, while the most studied mycotoxins produced by Fusarium species were ZEN, FBs, nivalenol (NIV), T-2, DON and its derivates. Since in the last decade attention toward unregulated/emerging mycotoxins increased, interactions of these mycotoxins as well as their interactions with major mycotoxins have also been extensively studied $[17,18]$. The effects of binary, tertiary and multiple mixtures of these mycotoxins in vitro have been studied on cell models originating from the digestive system, i.e., intestinal Caco-2 cells and hepatic HepG2 cells, or kidney cells like i.e., monkey kidney Vero cells, porcine PK15, human kidney HK2, and occasionally immune system-derived cells like THP-1 macrophages [18-21]. A number of studies examined the nature of interaction between mycotoxins both in vivo and in vitro classifying interaction effects into three types: antagonistic effect, additive effect, and synergistic effect $[18,19]$. The definition of each interaction effect is based on a comparison of observed effects with the expected effects of combination. If the observed effect is greater than expected, it is defined as a synergism, and if the opposite is true, i.e., if the observed effect is lesser than expected, it is defined as an antagonism. The third case, when the expected value is equal to the observed one is called an additive effect $[22,23]$. These simple definitions leave one problem though: estimations of expected effects for combinations of two non-interacting mycotoxins. Among the several available mathematical models that may be used to describe mycotoxin interactions, the arithmetic definition of additivity was the most commonly used one [24]. Other models included a factorial analysis of variance [25], Bliss independence criterion [26], Loewe's additivity law [27], response surface [28], combination index and isobologram analysis [29], Chou-Talalay's median effect approach [30], and the MixLow method [31]. These models will be discussed later on in this review. Additionally, the highest single agent model [32] and CISNE (code for the identification of synergism numerically efficient) [33], that have not been used so far in mycotoxicology, will also be discussed. 
The most comprehensive review on mycotoxin interactions in cell cultures of human and animal origin was given by Alassane-Kpembi et al. [18]; the majority of conducted studies used the arithmetic definition of additivity. In the studies conducted in the last four years (Tables 1 and 2) the interactions between mycotoxins in vitro were evaluated using more appropriate mathematical models than the arithmetic definition of additivity.

\section{Mathematical Models for Assessing Mycotoxin Interactions}

In this paper, $E$ will serve as an abbreviation for "effect" in equations. It is also assumed that effect is relative to maximal effect, i.e., percentage of cell viability suppression, where suppression is equal to difference between negative control (100\% viability) and treated cells (100\%-effect viability).

\subsection{Simple Addition of Effects}

The simplest method for estimating interactions between mycotoxins is the assumption of effect additivity known as arithmetic definition of additivity or response additivity (Equation (1)):

$$
\mathrm{E}_{\mathrm{exp}}=\mathrm{E}_{\mathrm{M} 1}+\mathrm{E}_{\mathrm{M} 2}
$$

where $E_{\text {exp }}$ is the expected effect of combination of mycotoxin $M_{1}$ in dose $D_{1}$ and mycotoxin $M_{2}$ in dose $D_{2}$, while $E_{M 1}$ and $E_{M 2}$ are the effects of single tested mycotoxins $M_{1}$ and $M_{2}$ in doses $D_{1}$ and $D_{2}$, respectively. That simple addition of effect was applied by Šegvić Klarić et al. [34] for assessing the combination effect of beauvericin (BEA) and OTA using Equation (1) and observed synergistic effect for two combinations. Mathematically, this approach would be incorrect most of the time because the dose-effect curve is not linear. Using the data on cytotoxicity of OTA alone of the mentioned paper, it is easy to see that using this method we can prove that OTA applied in combination with itself at concentrations of $5 \mu \mathrm{M}$ and $5 \mu \mathrm{M}$ revealed an antagonistic effect; the expected cell viability would be around $20 \%$, while the observed value for cell viability after treatment with $10 \mu \mathrm{M}$ ochratoxin A was around $50 \%$ (Figure 1). Interestingly, despite an inaccurate estimation of expected effects, this model was widely applied; Alassane-Kpembi et al. [18] in their review cited 52 studies out of 83 that used this method.

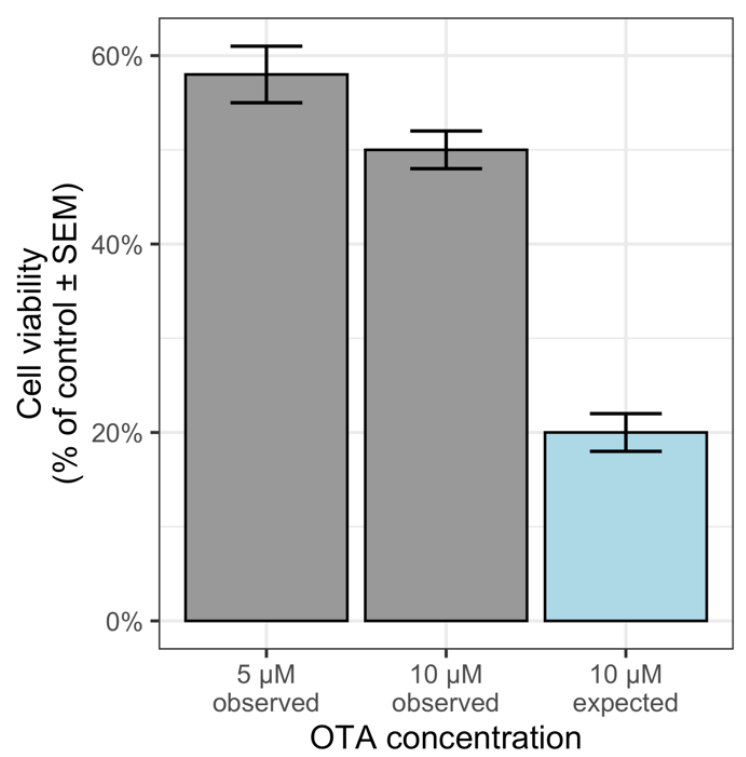

Figure 1. Cytotoxicity of OTA ( $5 \mu \mathrm{M}$ and $10 \mu \mathrm{M}$ observed) on PK15 cells after $24 \mathrm{~h}$ of exposure [34]; arithmetic additivity calculation shows that upon treatment with $5+5 \mu \mathrm{M}$ of OTA expected viability is much lower than observed viability indicating antagonism (no copyright permission needed as we created this figure). 
Some studies presented in Table $1[35,36]$ used simple addition of effects according to Weber et al. [24] who modified Equation (1) by subtracting the $100 \%$ (or 1 ) from the sum of the mean effects. Needless to say, the unexplained subtraction of $100 \%$ did not account for the non-linearity of the dose response curves.

\subsection{Factorial Analysis of Variance}

This model uses simple 2-way ANOVA for modelling the detection of interactions between two mycotoxins (Equation (2)):

$$
E=\beta_{0}+\beta_{1} \times D_{1}+\beta_{2} \times D_{2}+\beta_{3} \times D_{1} \times D_{2}
$$

where $E$ is the estimated effect, $\beta_{0}$ is the part of the effect achieved by negative control, $\beta_{1} / \beta_{2}$ is the coefficient that increases effect for each increase in one unit of dose $D_{1} / D_{2}$ of mycotoxin $M_{1} / M_{2}$ and $\beta_{3}$ is the interaction term.

Eight studies that have used this approach to define mycotoxin interactions were reviewed in detail by Alassane-Kpembi et al. [18]. If the interaction term was significantly (in a statistical manner) different than zero, it was concluded that an interaction between mycotoxins occurred. The main problem with this method is that ANOVA can be very misleading, similarly to the simple addition of effects method because ANOVA is based on linear modelling which is not useful for modelling nonlinear dose-effect curves [25]. This method was recently applied in only one study for testing the dual combination effects of ZEN and OTA or $\alpha$-ZEL in HepG2 cells [37], as summarized in Table 1.

\subsection{Bliss Independence Criterion}

Bliss introduced this model in 1939 for predicting the proportion of animals that will die after combining two toxins under the assumption that there is no interaction between the toxins (i.e., they have completely different mechanisms of action or act in different compartments):

$$
\mathrm{E}_{\exp }=1-\left(1-\mathrm{E}_{\mathrm{M} 1}\right) \times\left(1-\mathrm{E}_{\mathrm{M} 2}\right)=\mathrm{E}_{\mathrm{M} 1}+\mathrm{E}_{\mathrm{M} 2}-\mathrm{E}_{\mathrm{M} 1} \times \mathrm{E}_{\mathrm{M} 2}
$$

where $E_{\text {exp }}$ is the expected effect of a combination of mycotoxin $M_{1}$ in dose $D_{1}$ and mycotoxin $M_{2}$ in dose $D_{2}$, while $E_{M 1}$ and $E_{M 2}$ are the effects of single tested mycotoxins $M_{1}$ and $M_{2}$ in doses $D_{1}$ and $D_{2}$, respectively [26], all effects need to be expressed as proportions ranging from 0 to 1 (Equation (3)).

Similarly to the simple addition of effects, Bliss can result in a detection of an interaction of some mycotoxin with itself but that is not possible in model validation since this would a priori violate the assumption of two toxins acting independently.

Several of the recent studies listed in Table 1 simultaneously used different mathematical models, e.g., response additivity and Bliss independence criterion $[38,39]$ or Bliss independence and Loewe additivity [40] or Chou-Talalay method $[39,41]$. As expected, these studies obtained different conclusions on mycotoxin interactions depending on the mathematical models that have been applied. For example, Smit et al. [39] obtained a synergism of DON + ZEN at low and medium concentrations by both response additivity and Bliss independence model; while at high concentrations in combinations, an additive effect was obtained with Bliss independence model and antagonism by response additivity.

\subsection{Loewe's Additivity Law}

Loewe's additivity law (also called isobolografic method, concentration additivity or dose additivity) assumes that mycotoxins act within the same compartment on the same biological size by the same mechanism. The only difference is in their potency. This model is based on the dose equivalence principle and the sham combination principle; in short, every dose $D_{1}$ of mycotoxin $M_{1}$ gives an equal effect as $D_{2(1)}$ of mycotoxin $M_{2}$, and vice versa, and any $D_{2(1)}$ can be added to any other dose of $\mathrm{D}_{2}$ to show the additive effect [27] as presented by Equation (4): 


$$
\mathrm{E}\left(\mathrm{D}_{1}+\mathrm{D}_{2}\right)=\mathrm{E}\left(\mathrm{D}_{1}+\mathrm{D}_{1(2)}\right)=\mathrm{E}\left(\mathrm{D}_{2(1)}+\mathrm{D}_{2}\right)
$$

where $E$ is the effect, $D_{1}$ is the dose of mycotoxin $M_{1}, D_{2}$ is the dose of mycotoxin $M_{2}, D_{1(2)}$ dose of mycotoxin $\mathrm{M}_{1}$ that provokes same effect as $\mathrm{D}_{2}$ dose of mycotoxin $\mathrm{M}_{2}, \mathrm{D}_{2(1)}$ dose of mycotoxin $\mathrm{M}_{2}$ that provokes same effect as $\mathrm{D}_{1}$ of mycotoxin $\mathrm{M}_{1}$. For additive effects, the following Equation (5) is valid:

$$
\mathrm{D}_{1} / \mathrm{D}_{\mathrm{E} 1}+\mathrm{D}_{2} / \mathrm{D}_{\mathrm{E} 2}=1
$$

where $D_{1}$ and $D_{2}$ are the doses of mycotoxins $M_{1}$ and $M_{2}$ applied in combination, and $D_{E 1}$ and $D_{E 2}$ are the dose of mycotoxin $\mathrm{M}_{1}$ and $\mathrm{M}_{2}$ applied alone. All doses $\left(\mathrm{D}_{1}+\mathrm{D}_{2}, \mathrm{D}_{\mathrm{E} 1}\right.$ or $\left.\mathrm{D}_{\mathrm{E} 2}\right)$ result with the same effect E.

Additionally, Loewe's additivity law makes a larger number of assumptions; each mycotoxin in a mixture must have an equal maximum effect and all $\log$ (dose)-effect curves must be parallel and have constant relative potency [42,43], according to Equation (6):

$$
\left(\mathrm{R}=\mathrm{D}_{\mathrm{E} 1} / \mathrm{D}_{\mathrm{E} 2}\right)
$$

Finding two mycotoxins in a combination that fulfils all of these assumptions seems somewhat impossible. For example, apart from the Bliss independence criterion, Li et al. [44] also used this method (as a concentration addition model) to assess the nature of interaction between OTA and ZEN. Since their dose-effect curves did not meet all of the assumptions, it is easy to see that Equation (4), on which Loewe's additivity law is based, does not hold true when we assign the values $\mathrm{EC}_{10}(\mathrm{OTA})=0.8 \mu \mathrm{M}$ and $\mathrm{EC}_{10}(\mathrm{ZEN})=11.84 \mu \mathrm{M}$ [44], and try to apply the main principles of dose equivalence and sham combination of this model (Equations (7) and (8)):

$$
\begin{gathered}
\mathrm{E}\left(\mathrm{EC}_{10 \text { OTA }}+\mathrm{EC}_{10 \mathrm{ZEN}}\right)=\mathrm{E}\left(\mathrm{EC}_{10 \text { OTA }}+\mathrm{EC}_{10 \text { OTA }}\right)=\mathrm{E}\left(\mathrm{EC}_{10 \mathrm{ZEN}}+\mathrm{EC}_{10 \mathrm{ZEN}}\right) \\
\mathrm{E}(2 \times 0.8 \mu \mathrm{M} \text { of OTA })=\mathrm{E}(2 \times 11.84 \mu \mathrm{M} \text { of } \mathrm{ZEN})
\end{gathered}
$$

This does not seem to be correct according to the dose-response curves for OTA (E (1.60 $\mu \mathrm{M}$ of $\mathrm{OTA}) \approx 30 \%)$ and ZEN $(\mathrm{E}(23.68 \mu \mathrm{M}$ of $\mathrm{ZEN}) \approx 50 \%)$ presented in aforementioned article [44], which raises the question: can the observed synergies be trusted at all?

Even though this model is mathematically valid, due to the excessive number of assumptions that need to be fulfilled, this model probably remains inapplicable for assessing combinations of mycotoxins [43].

\subsection{Response Surface}

Some authors expanded the Loewe's additivity law and Bliss independence criterion to the whole surface defined by all predicted additive concentration combinations (in all ratios, for all effects) $[45,46]$ as presented in Table 1. In mycotoxicology, Assunção et al. [46] implemented model generalization built by Jonker et al. [28]. They estimated the deviation from Loewe's additivity law by Equation (9):

$$
\mathrm{D}_{1} / \mathrm{D}_{\mathrm{E} 1}+\mathrm{D}_{2} / \mathrm{D}_{\mathrm{E} 2}=\mathrm{e}^{\mathrm{G}}
$$

where $G$ is the deviation function defined separately for 4 models. If $G=0$, then Equation (9) collapses to Equation (5), suggesting an additive effect. To test for synergism or antagonism $G$ is substituted with (Equation (10)):

$$
\mathrm{G}\left(\mathrm{z}_{1}, \mathrm{z}_{2}\right)=\mathrm{a} \times \mathrm{z}_{1} \times \mathrm{z}_{2}
$$

where parameter $\mathrm{a}$ is less than zero for synergisms and greater than zero for antagonisms, $\mathrm{z}_{1}$ and $\mathrm{z}_{2}$ are relative contribution to toxicity, i.e., for $z_{1}$ as presented by Equation (11):

$$
\mathrm{z}_{1}=\mathrm{D}_{1} / \mathrm{D}_{\mathrm{E} 1} /\left(\mathrm{D}_{1} / \mathrm{D}_{\mathrm{E} 1}+\mathrm{D}_{2} / \mathrm{D}_{\mathrm{E} 2}\right)
$$


Jonker et al. [28] also define more complicated interaction patterns between two toxins and with the inclusion of parameters $b_{1}$ for detection of dose ratio-dependent deviation (Equation (12)), and parameters $b_{\mathrm{DL}}$ for the detection of dose level-dependent deviations (Equation (13)) from a non-interacting additive model:

$$
\begin{gathered}
G\left(z_{1}, z_{2}\right)=\left(a+b_{1} \times z_{1}\right) \times z_{1} \times z_{2} \\
G\left(z_{1}, z_{2}\right)=a \times\left(1-b_{D L} \times\left(D_{1} / D_{M 1}+D_{2} / D_{M 2}\right)\right) \times z_{1} \times z_{2}
\end{gathered}
$$

The procedure by Jonker et al. [28] suggests fitting all four models (defined by four deviation functions) and then choosing the best one to make conclusions about the nature of the interaction at different dose ratios or dose levels based on parameters $a, b_{1}$, and $b_{D L}$ according to Table 1 of Jonker et al. [28].

This method provides more information than the other methods mentioned in this article, but it comes with a greater cost of the experiment since a checkerboard experimental design is needed, with dense concentration ranges in all combinations.

\subsection{Highest Single Agent (HSA) Model}

This model is also referred to as the Gaddums non-interaction [32], it defines the expected effect as the maximum of single mycotoxin effects (Equation (14)):

$$
\mathrm{E}_{\mathrm{exp}}=\max \left(\mathrm{E}_{\mathrm{M} 1}, \mathrm{E}_{\mathrm{M} 2}\right)
$$

where $E_{\text {exp }}$ is the expected effect of a combination of mycotoxin $M_{1}$ in dose $D_{1}$ and mycotoxin $M_{2}$ in dose $D_{2}$, while $E_{M 1}$ and $E_{M 2}$ are the effects of single tested mycotoxins $M_{1}$ and $M_{2}$ in doses $D_{1}$ and $\mathrm{D}_{2}$, respectively.

Because of underestimations of the expected combination effect, this model is not appropriate for detection of synergistic effects, except in cases: (i) where one compound is completely inactive at any concentration for the measured effect (which is rare in the field of mycotoxins); (ii) where a mycotoxin with maximal effect does not reach full effect (i.e., never suppresses viability to $0 \%$ ). On the other hand, this method is useful for detecting antagonistic effects since observing a combination effect less than the maximal effect of a mycotoxin alone clearly demonstrates an interaction of antagonistic nature. However, underestimations of the expected combination effect can hide milder antagonistic effects. The great advantage of this model is the financial cost of the experiment: to prove an antagonistic effect, it is sufficient to test three concentrations, each mycotoxin alone and a combination of the mycotoxins. Another advantage is that this method is also independent of the mechanism of action, and it does not make any assumptions on the dose-effect curve. However, this simple approach has never been applied in mycotoxicology. 
Table 1. Interactions between mycotoxin combinations in vitro assessed by simple addition of effects, full factorial analysis, Bliss independence criterion, Loewe additivity law and response surface.

\begin{tabular}{|c|c|c|c|c|}
\hline $\begin{array}{l}\text { Mycotoxin } \\
\text { Combination }\end{array}$ & $\begin{array}{c}\text { In Vitro } \\
\text { Model }\end{array}$ & $\begin{array}{l}\text { Mathematical Model } \\
\text { Applied for the Endpoint }\end{array}$ & Endpoint Combined Effect & Reference \\
\hline $\mathrm{AFM}_{1}+\mathrm{OTA}$ & $\begin{array}{c}\text { Caco-2/ human colon } \\
\text { HT29-MTX co-cultures } \\
(100 / 0,90 / 10,75 / 25 \text { and } \\
0 / 100)\end{array}$ & Simple addition of effects & $\begin{array}{c}\text { Cell viability (Enhanced Cell Counting Kit-8, CCK-8): } \\
\text { synergism in all cultures } \\
\text { TEER: } \\
\text { co-culture } \\
\text { antagonism in all cultures, except additive effect in 90/10 } \\
\text { Intestinal mucin } M U C 2 \text { and MUC5B mRNA expression: } \\
\text { synergistic effect in } 75 / 25 \text { and } 0 / 100 \text { cultures at } 4 \mu \mathrm{g} / \mathrm{mL} \\
\text { additive effects at the low concentration }(0.05 \mu \mathrm{g} / \mathrm{mL} \text { ) culture, } \\
\text { antagonistic effects in } 100 / 0 \text { and } 90 / 10 \text { cultures at } 4 \mu \mathrm{g} / \mathrm{mL} \\
\text { Intestinal mucin } M U C 5 A C \text { mRNA expression: } \\
\text { antagonistic effect in } 100 / 0 \text { cultures, an additive effect in } 0 / 100 \\
\text { cultures at two concentrations of the mixtures } \\
\text { Intestinal mucin MUC5AC, MUC2 AND MUC5B on protein level: } \\
\text { synergism at } 0.05 \text { and } 4 \mu \mathrm{g} / \mathrm{mL} \\
\text { additive effect at } 0.05 \mu \mathrm{g} / \mathrm{mL} \text { in } 75 / 25 \text { and } 90 / 10 \text { cultures }\end{array}$ & [35] \\
\hline $\mathrm{AFB}_{1}+\mathrm{FB}_{1}$ & HepG2 cells & $\begin{array}{l}\text { Simple addition of effects } \\
\text { and factorial analysis } \\
\text { (two-way ANOVA) }\end{array}$ & $\begin{array}{l}\text { Cell cycle analysis (flow citometry assay): } \\
\text { synergism on apoptosis at } 10 \% \text { and } 30 \% \text { of } \mathrm{IC}_{50}\end{array}$ & [36] \\
\hline $\begin{array}{l}\text { ZEN }(30 \text { or } 60 \mu \mathrm{M})+ \\
\text { OTA }(6 \text { or } 12 \mu \mathrm{M}) \\
\text { ZEN }(30 \text { or } 60 \mu \mathrm{M})+ \\
\alpha \text {-ZEL }(15 \text { or } 30 \mu \mathrm{M})\end{array}$ & HepG2 cells & $\begin{array}{c}\text { Full factorial analysis: } \\
3 \times 3 \text { two-way } \\
\text { ANOVA matrix }\end{array}$ & $\begin{array}{c}\text { Cytotoxicity (MTT test): } \\
\text { synergism of ZEN }(60 \mu \mathrm{M})+\alpha \text {-ZEL }(15 \text { or } 30 \mu \mathrm{M}) \\
\text { antagonism in all other combinations } \\
\text { Oxidative stress parameters (MDA, GSH, Gpx, SOD): } \\
\text { synergism of ZEN }(60 \mu \mathrm{M})+\alpha \text {-ZEL }(15 \text { or } 30 \mu \mathrm{M}) \\
\text { antagonism in all other combinations }\end{array}$ & [37] \\
\hline $\mathrm{DON}+\mathrm{ZEN}$ & $\begin{array}{l}\text { Bi- and tri-culture systems: } \\
\text { A) Caco-2 and HepaRG; } \\
\text { B) Caco-2 and THP-1; } \\
\text { C) HepaRG and THP-1 D) } \\
\text { Caco-2, HepaRG and THP-1 }\end{array}$ & $\begin{array}{l}\text { Response additivity, } \mathrm{CI}_{\mathrm{RA}} \text { ) } \\
\text { and Bliss independence } \\
\text { criterion (independent } \\
\left.\text { joint action, } \mathrm{CI}_{\mathrm{jj}}\right) ; \mathrm{IC}_{10} \\
\quad(1: 1) \text { and } \mathrm{IC}_{30}(1: 1)\end{array}$ & $\begin{array}{l}\text { Cytotoxicity (MTS test): } \\
\text { additive effect for combination of } \mathrm{IC}_{10} \text { in } \mathrm{A}-\mathrm{D}\left(\mathrm{CI}_{\mathrm{RA}} \text { and } \mathrm{CI}_{\mathrm{IjA}}\right) \\
\text { synergism for combination of } \mathrm{IC}_{30} \text { in } \mathrm{A}-\mathrm{C}\left(\mathrm{CI}_{\mathrm{RA}} \text { and } \mathrm{CI}_{\mathrm{IjA}}\right) \\
\text { additive effect for combination of } \mathrm{IC}_{30} \text { in } \mathrm{D}\left(\mathrm{CI}_{\mathrm{RA}} \text { and } \mathrm{CI}_{\mathrm{IjA}}\right)\end{array}$ & [38] \\
\hline
\end{tabular}


Table 1. Cont

\begin{tabular}{|c|c|c|c|c|}
\hline $\begin{array}{l}\text { Mycotoxin } \\
\text { Combination }\end{array}$ & $\begin{array}{l}\text { In Vitro } \\
\text { Model }\end{array}$ & $\begin{array}{l}\text { Mathematical Model } \\
\text { Applied for the Endpoint }\end{array}$ & Endpoint Combined Effect & Reference \\
\hline $\begin{array}{c}\mathrm{DON}+\mathrm{MON} \\
\mathrm{DON}+\mathrm{FB}_{1} \\
\mathrm{DON}+\mathrm{ZEN} \\
\mathrm{NIV}+\mathrm{T}-2\end{array}$ & HepaRG cells & $\begin{array}{l}\text { Response additivity }\left(\mathrm{CI}_{\mathrm{RA}}\right) \\
\text { and Bliss independence } \\
\text { criterion (independent } \\
\left.\text { joint action, } \mathrm{CI}_{\mathrm{IjA}}\right)\end{array}$ & $\begin{array}{c}\text { Cytotoxicity (MTS): } \\
\text { synergism of DON }+ \text { MON in all combinations except additive } \\
\text { effect at highest concentration }(1: 1)\left(\mathrm{CI}_{\mathrm{RA}} \text { and } \mathrm{CI}_{\mathrm{IjA}}\right) \\
\text { synergism of DON }+\mathrm{FB}_{1} \text { in all combinations }\left(\mathrm{CI}_{\mathrm{RA}} \text { and } \mathrm{CI}_{\mathrm{IjA}}\right) \\
\text { except additive effect at highest concentration }(1: 1)\left(\mathrm{CI}_{\mathrm{RA}}\right) \\
\text { synergism of DON }+\mathrm{ZEN} \text { at low and medium concentrations } \\
\left(\mathrm{CI}_{\mathrm{RA}} \text { and } \mathrm{CI}_{\mathrm{IjA}}\right) ; \text { additive effect }\left(\mathrm{CI}_{\mathrm{IJA}}\right) \text { and antagonism at high } \\
\text { concentrations }\left(\mathrm{C}_{\mathrm{RA}}\right) \\
\mathrm{NIV}+\mathrm{T}-2 \text { synergism at low concentrations }\left(\mathrm{CI}_{\mathrm{RA}} \text { and } \mathrm{CI}_{\mathrm{IjA}}\right) ; \\
\text { additive effect or antagonism }\left(\mathrm{CI}_{\mathrm{IJA}}\right) \text { and antagonism at medium } \\
\text { and high concentrations }\left(\mathrm{CI}_{\mathrm{RA}}\right)\end{array}$ & [39] \\
\hline $\begin{array}{c}\mathrm{AFB}_{1}+\mathrm{ZEN} \\
\mathrm{AFB} 1+\mathrm{DON} \\
\mathrm{ZEN}+\mathrm{DON} \\
\mathrm{AFB} 1+\mathrm{ZEN}+\mathrm{DON}\end{array}$ & HepG2 cells & $\begin{array}{l}\text { Bliss independence } \\
\text { criterion (IA) and Loewe } \\
\text { additivity models (CA); } \\
\text { CI-Isobologram method }\end{array}$ & $\begin{array}{c}\text { Cell number (high content analysis by fluorescent labelling: } \\
\text { IA and CA model: deviation from the obtained results; better } \\
\text { consistency was achieved by CA model; } \\
\text { CI model: antagonism at low fraction affected }(0.05-0.15) \\
\text { changing to additive and synergistic effect as fraction affected } \\
\text { increases for all combinations }\end{array}$ & [40] \\
\hline $\begin{array}{c}\text { TeA + ENN B; TeA + } \\
\text { ZEN; TeA + DON; TeA } \\
\text { + NIV; TeA + AURO; } \\
\text { ENN B + ZEN; ENN B } \\
\text { + DON; ENN B + NIV } \\
\text { ENN B + AURO; ZEN } \\
\text { + DON; ZEN + NIV; } \\
\text { ZEN + AURO; DON + } \\
\text { NIV; DON + AURO }\end{array}$ & Caco- 2 cells & $\begin{array}{l}\text { Bliss independence } \\
\text { criterion combined with } \\
\text { CI calculated by Chou }(\mathrm{C}) \\
\text { and Chou-Talalay }(\mathrm{CT}) \\
\text { method }\end{array}$ & $\begin{array}{c}\text { Cytotxicity (WST-1 test): } \\
\text { additive effects of binary mixtures at low concentrations } \\
\text { calculated by Bliss independence criterion } \\
\text { antagonism of binary mixtures ENN B, ZEN and DON as well as } \\
\text { binary combinations of Fusarium toxins with TeA applied at } \\
\text { cytotoxic concentrations as calculated by CI }\end{array}$ & [41] \\
\hline $\mathrm{ATX} \mathrm{II}+\mathrm{AOH}$ & $\begin{array}{l}\text { HepG2, HT29 cells and } \\
\text { human corneal epithelial } \\
\text { HCEC cells }\end{array}$ & $\begin{array}{c}\text { Bliss independence } \\
\text { criterion, constant ratio of } \\
1: 10 \text { or } 1: 1\end{array}$ & $\begin{array}{c}\text { Cytotoxicity (WST-1 test): } \\
\text { dominant additive effect in all cell lines } \\
\text { antagonism in specific doses of ratios 1:10 or 1:1 }\end{array}$ & [47] \\
\hline
\end{tabular}


Table 1. Cont

\begin{tabular}{|c|c|c|c|c|}
\hline $\begin{array}{l}\text { Mycotoxin } \\
\text { Combination }\end{array}$ & $\begin{array}{l}\text { In Vitro } \\
\text { Model }\end{array}$ & $\begin{array}{c}\text { Mathematical Model } \\
\text { Applied for the Endpoint }\end{array}$ & Endpoint Combined Effect & Reference \\
\hline $\begin{array}{c}\mathrm{AOH}+\mathrm{DON} \\
\mathrm{AOH}+\mathrm{ZEN} \\
\mathrm{ZEN}+\mathrm{DON} \\
\mathrm{AOH}+\mathrm{DON}+\mathrm{ZEN}\end{array}$ & $\begin{array}{l}\text { THP-1 monocytes } \\
\text { differentiated into } \\
\text { macrophages }\end{array}$ & $\begin{array}{l}\text { Concentration addition } \\
\text { (CA) and independent } \\
\text { action (IA) model at equal } \\
\text { effect concentration }\end{array}$ & $\begin{array}{c}\text { CD14 expression: } \\
\text { synergism of } \mathrm{AOH}+\mathrm{DON} \text { applied at low concentrations } \\
\text { additive effects of binary and tertiary mixtures of AOH, ZEN and } \\
\text { DON, as calculated by both CA and IA }\end{array}$ & [48] \\
\hline $\begin{array}{l}\text { CIT + OTA } \\
\text { OTA + PAT } \\
\text { OTA + MPA } \\
\text { OTA + PA } \\
\text { CIT + PAT } \\
\text { CIT + MPA } \\
\text { CIT + PA } \\
\text { PAT + MPA } \\
\text { PAT + PA } \\
\text { MPA + PA }\end{array}$ & $\begin{array}{c}\text { Bovine peritoneal } \\
\text { macrophage BoMacs cells }\end{array}$ & $\begin{array}{l}\text { CA and IA model; } \\
\text { Penicillium toxins in } \mathrm{IC}_{25} \\
\frac{1}{2} \mathrm{IC}_{25} \text { and } \frac{1}{4} \mathrm{IC}_{25}\end{array}$ & $\begin{array}{c}\text { Cell proliferation (CyQUANT }{ }^{\circledR} \text { GR dye): } \\
\text { CIT + OTA synergism at } \frac{1}{2} \mathrm{IC}_{25} \text { (CA, IA) } \\
\text { OTA + PAT additive effects (CA, IA) } \\
\text { OTA + MPA synergism at } \mathrm{IC}_{25}, \frac{1}{2} \mathrm{IC}_{25} \text { and } \frac{1}{4} \mathrm{IC}_{25}(\mathrm{CA}) \\
\text { OTA + PA synergism at } \mathrm{IC}_{25} \text { and } \frac{1}{4} \mathrm{IC}_{25}(\mathrm{CA}) \\
\text { - CIT + PAT antagonism at } \frac{1}{2} \mathrm{IC}_{25} \text { (CA) } \\
\text { CIT + MPA inconclusive (synergism CA, antagonism IA) } \\
\text { CIT + PA antagonism at } \mathrm{IC}_{25}, \frac{1}{2} \mathrm{IC}_{25} \text { (IA) } \\
\text { PAT + MPA antagonism at } \mathrm{IC}_{25}, \frac{1}{2} \mathrm{IC}_{25} \text { and } \frac{1}{4} \mathrm{IC}_{25}(\mathrm{IA}) \\
\text { PAT + PA synergism at } \frac{1}{2} \mathrm{IC}_{25} ; \text { antagonism at } \mathrm{IC}_{25} \\
\text { MPA + PA inconclusive }\end{array}$ & [45] \\
\hline OTA + PAT & Caco- 2 cells & $\begin{array}{l}\text { Concentration addition } \\
\text { model (CA) and } \\
\text { independent action (IA) } \\
\text { model with Jonker's } \\
\text { generalization [28] }\end{array}$ & $\begin{array}{c}\text { Cytotoxicity (MTT test): } \\
\text { - additive effects (CA) } \\
\text { synergism at high concentration of OTA and low of PAT (IA) } \\
\text { antagonism at high concentration of PAT and low of OTA (IA) } \\
\text { Gastrointestinal barrier integrity (TEER assay): } \\
\text { synergism at low concentration and antagonism at high } \\
\text { concentration; the change from synergism to antagonism at } \\
\text { higher IC } 50 \text { level (CA, IA) } \\
\text { Genotoxicity (alkaline comet test): } \\
\text { no dose-effect relationship of the single toxins; mathematical } \\
\text { modelling was not applicable for the mixture }\end{array}$ & [46] \\
\hline
\end{tabular}




\subsection{Combination Index and Isobologram Analysis}

Applying Loewe's additivity law or similar methods can allow researchers to use the Interaction/combination index which is based on Equation (5) for describing the nature of the combination effect (Equation (15)):

$$
\mathrm{CI}=\mathrm{D}_{1} / \mathrm{D}_{\mathrm{E} 1}+\mathrm{D}_{2} / \mathrm{D}_{\mathrm{E} 2},
$$

where $\mathrm{CI}$ is the interaction/combination index: $\mathrm{CI}<1$ indicates synergism, $\mathrm{CI}=1$ indicates an additive effect and CI $>1$ indicates an antagonism [29]. Isobologram analysis is just a "fancy" name for the graphical representation of the combination index for the same effect in different ratios of two mycotoxins. It is a simple plot with the dose/concentration of mycotoxin 1 on the $\mathrm{x}$ axis and the dose/concentration of mycotoxin 2 on the y axis. The characteristic line, isobole, connects the y intercept and $x$ intercept which represents the doses needed for achieving a defined effect (i.e., $50 \%$ ) for single acting mycotoxins. Plotting the dot with coordinates of doses in combination that achieve the same defined effect gives us a clue about the nature of the combination effect. All of the dots below the isobole indicate synergy, the dots above the isobole indicate antagonism, while the dots on the isobole indicate a possible additive effect [49]. The combination index and isobologram method were applied in 15 studies reviewed in Alassane-Kpembi et al. [18] and was the second most used method for assessing mycotoxin interactions and much more appropriate than the arithmetic definition of additivity or factorial design.

The problems of not meeting the assumptions of Loewe's additivity law affect the combination index and isobologram. For example, if the two dose-response curves are not parallel, instead of one linear isobole, there will be two curvilinear isoboles around the former, linear one. The area between the two new curvilinear isoboles is not an area of synergy, nor is it an area of antagonism [43]. A recent study by Anastasiadi et al. [50] generalized the Loewe's model accounting for nonparallel dose-response curves. As a result, Equation (15) was expanded to Equation (16):

$$
\mathrm{CI}=\left(\mathrm{D}_{1} / \mathrm{D}_{\mathrm{E} 1}\right)^{\mathrm{m} 1 / \mathrm{m} 2}+\mathrm{D}_{2} / \mathrm{D}_{\mathrm{E} 2}, \quad \mathrm{~m}_{1}<\mathrm{m}_{2}
$$

where $\mathrm{m}_{1}$ and $\mathrm{m}_{2}$ are the slopes of the dose-response curves for mycotoxin 1 and mycotoxin 2 .

Recently we tested the cytotoxicity (MTT test, $24 \mathrm{~h}$ ) of single CIT, STC and 5-M-STC and dual combinations of CIT with STC and 5-M-STC in A549 cells (Table 2). The cytotoxicity of the mycotoxins was as follows: 5-M-STC $\left(\mathrm{IC}_{50}=5.5 \mu \mathrm{M}\right)>\mathrm{STC}\left(\mathrm{IC}_{50}=60 \mu \mathrm{M}\right)>\mathrm{CIT}\left(\mathrm{IC}_{50}=128 \mu \mathrm{M}\right)$. Mycotoxin interactions of 1:1, 1:2 and 2:1 of $\mathrm{IC}_{50}$ concentration ratios were tested by applying a concentration addition model with correction for unparalleled dose-response curves as developed by Anastasiadi et al. [50], as presented in Figure 2.

\subsection{Chou and Talalay's Median Effect Approach}

Chou and Talalay developed a unified general theory for the Michaelis-Menten, Hill, Henderson-Hasselbalch, and Scatchard equations, mathematically presented by Equation (17):

$$
\mathrm{E}=1 / 1+\left(\mathrm{D}_{\mathrm{M}} / \mathrm{D}\right)^{\mathrm{m}}
$$

where $\mathrm{E}$ is the effect (between 0 and 1), $\mathrm{D}$ is the dose, $\mathrm{D}_{\mathrm{M}}$ is the median effective dose (i.e., $\mathrm{EC}_{50}$ ) and $\mathrm{m}$ is a parameter for shape definition (if $\mathrm{m}<1$ dose-effect curve is hyperbolic, and if $\mathrm{m} \geq 1$ dose-effect curve is sigmoidal) [30]. Using Equation (17), it is possible to estimate the doses needed to achieve a particular effect which can be used in Equation (15) for the estimation of CI, which is then used for assessing the nature of the combination effect. Similarly to Loewe's additivity model, the isobologram can be constructed. The Chou-Talalay model combined with an isobologram has been applied in the majority of the recently published studies [39,51-65] listed in Table 2. Its great advantage is the recent development of a method for the estimation of confidence intervals for the combination index which 
enables the application of statistics [66]. This method can easily be implemented using the web-based CalcuSyn software which automatically calculates dose-effect curves and combination indices.
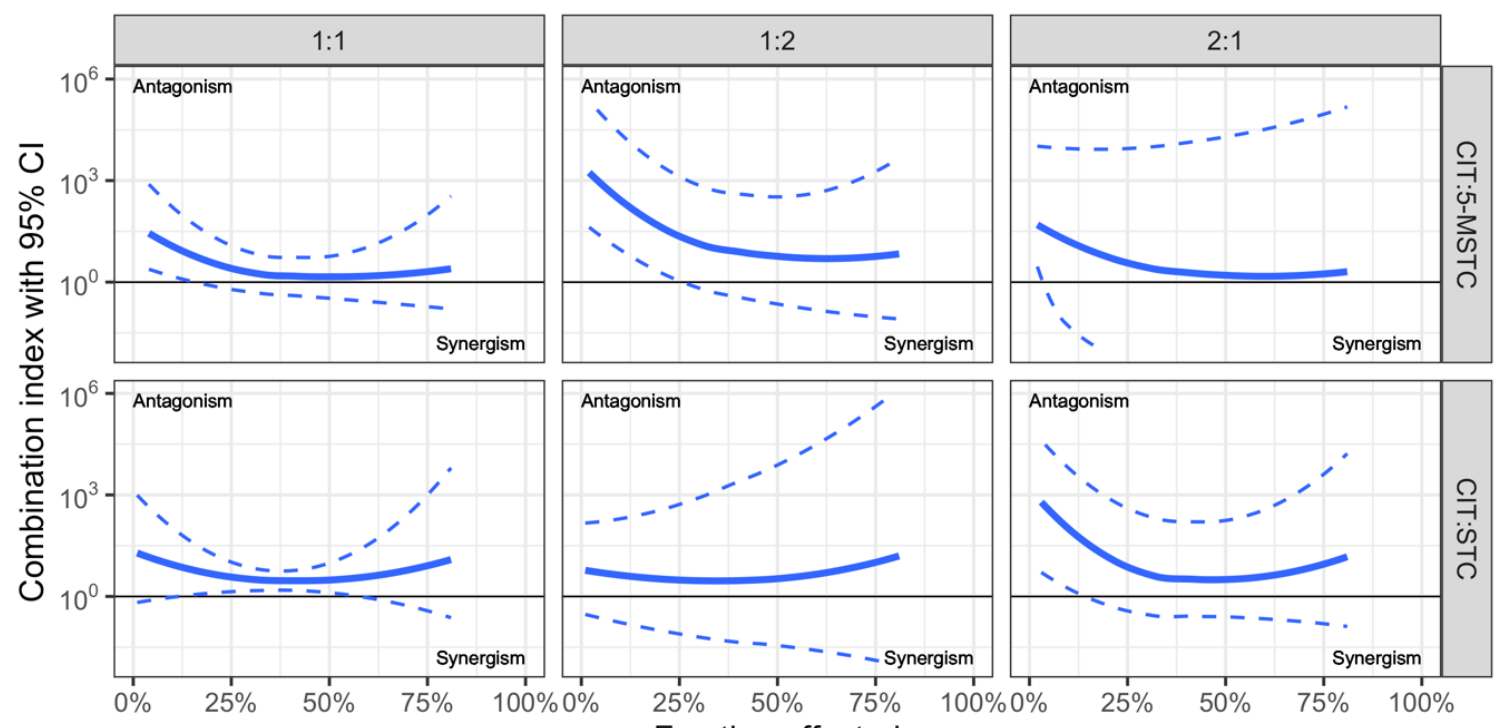

Figure 2. Combination indices calculated according to Anastasiadi et al. [50] accounting for different slopes of dose-response curves, 95\% confidence interval (CI) was estimated using Monte Carlo simulations $(\mathrm{N}=10000)$. All dose-response curves were fitted using non-linear regression. Results show mostly additive effect, with an exception of CIT + 5-M-STC combination which shows antagonistic effect in the area of up to $20 \%$ of cells affected, and CIT + STC combination (only $1 \mathrm{IC}_{50}: 1 \mathrm{IC}_{50}$ ratio) in the area of $25-50 \%$ of cells affected. 
Table 2. Interactions between mycotoxin combinations in vitro assessed by isobologram and Choul-Talalay method as well as MixLow model.

\begin{tabular}{|c|c|c|c|c|}
\hline $\begin{array}{l}\text { Mycotoxin } \\
\text { Combination }\end{array}$ & $\begin{array}{l}\text { In Vitro } \\
\text { Model }\end{array}$ & $\begin{array}{c}\text { Mathematical Model } \\
\text { Applied for the Endpoint }\end{array}$ & Endpoint Combined Effect & Reference \\
\hline $\begin{array}{l}\mathrm{AOH}(50 \mathrm{nM}-10 \mu \mathrm{M})+ \\
\mathrm{ZEN}(10 \mathrm{pM}-1 \mathrm{nM}) \\
\mathrm{AOH}(50 \mathrm{nM}-10 \mu \mathrm{M})+ \\
\alpha-\mathrm{ZEL}(1 \mathrm{pM}-1 \mathrm{nM})\end{array}$ & $\begin{array}{l}\text { Human endometrial } \\
\text { adenocarcinoma } \\
\text { cell line, Ishikawa }\end{array}$ & $\begin{array}{l}\text { Chou and Chou-Talalay } \\
\text { method }\end{array}$ & $\begin{array}{c}\text { Estrogenic effect (AIP test) according to C: } \\
61 \% \text { synergism, } 10 \% \text { additive effect, } 32 \% \text { antagonism for } \mathrm{AOH}+ \\
\text { ZEN } \\
86 \% \text { synergism, } 14 \% \text { antagonism for } \mathrm{AOH}+\alpha-\mathrm{ZEL} \\
\text { Estrogenic effect (AIP assay) according to CT: } \\
\text { ZEN or } \alpha \text {-ZEL:AOH (1:250) dominant synergism } \\
\text { Cytotoxicity (SRB assay): } \\
\text { not possible to calculate CI }\end{array}$ & {$[51]$} \\
\hline $\mathrm{DON}+\mathrm{T} 2$ & $\begin{array}{c}\text { Human chondrocytic C28/I2, } \\
\text { human hepatic epithelial L-02 } \\
\text { and human tubular epithelial } \\
\text { HK-2 cells }\end{array}$ & $\begin{array}{l}\text { CI-Isobologram according to } \\
\text { Chou-Talalay method; CI at } \\
\qquad \mathrm{IC}_{10-90}(1: 1)\end{array}$ & $\begin{array}{c}\text { Cytotoxicity (MTT test): } \\
\text { synergism at } \mathrm{IC}_{10} \text { in HK2 } \\
\text { antagonism in C28/12, L-02 }\left(\mathrm{IC}_{10-90}\right) \text { and in } \mathrm{HK} 2\left(\mathrm{IC}_{25-90}\right)\end{array}$ & {$[58]$} \\
\hline $\begin{array}{l}\text { DON + 15-ADON (1:1) } \\
\text { DON + FX (3:1) } \\
\text { DON + NIV (3:1) } \\
15-A D O N+\text { FX }(3: 1) \\
15-A D O N+\text { NIV }(3: 1) \\
\text { FX + NIV }(1: 1)\end{array}$ & $\begin{array}{l}\text { Human gastric epithelial } \\
\text { GES-1 cells }\end{array}$ & $\begin{array}{l}\text { CI-Isobologram according to } \\
\text { Chou-Talalay method; CI at } \\
\qquad \mathrm{IC}_{10}-\mathrm{IC}_{90}\end{array}$ & $\begin{array}{c}\text { Cytotoxicity (OD test): } \\
\text { synergism of DON }+15-\mathrm{ADON}, \mathrm{DON}+\mathrm{NIV}, \mathrm{FX}+\mathrm{NIV} \text { at } \\
\mathrm{IC}_{10}-\mathrm{IC}_{70} ; \mathrm{DON}+\mathrm{FX} \text { at } \mathrm{IC}_{10} \text { and } \mathrm{IC}_{30} ; 15-\mathrm{ADON}+\mathrm{FX} \text { at } \mathrm{IC}_{10} \\
\text { additive effect of FX }+\mathrm{NIV} \text { at IC } 90 \\
\text { antagonism of } 15 \mathrm{~A}-\mathrm{DON}+\mathrm{NIV} \text { at } \mathrm{IC}_{10}-\mathrm{IC}_{90} ; 15-\mathrm{ADON}+\mathrm{FX} \text { at } \\
\mathrm{IC}_{30}-\mathrm{IC}_{90} ; \mathrm{DON}+\mathrm{FX} \text { at } \mathrm{IC}_{50}-\mathrm{IC}_{90} ; \mathrm{DON}+15-\mathrm{ADON}, \mathrm{DON}+ \\
\mathrm{NIV}, \mathrm{FX}+\mathrm{NIV} \text { at IC } \mathrm{C}_{90}\end{array}$ & [59] \\
\hline $\begin{array}{c}\mathrm{AFB}_{1}+\mathrm{DON} \\
\mathrm{AFB}_{1}+\mathrm{ZEN} \\
\mathrm{DON}+\mathrm{ZEN} \\
\mathrm{AFB}_{1}+\mathrm{DON}+\mathrm{ZEN}\end{array}$ & $\begin{array}{l}\text { HepG2 and (murine leukemia } \\
\text { virus-induced tumor RAW } \\
264.7 \text { cells }\end{array}$ & 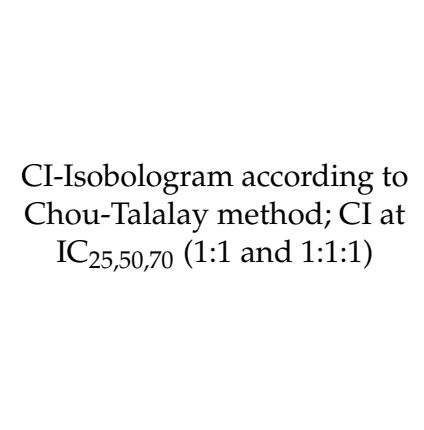 & $\begin{array}{c}\text { Cytotoxicity (Resazurin test) in HepG2: } \\
\text { synergism of DON + ZEN } \\
\mathrm{AFB}_{1}+\mathrm{DON}+\mathrm{ZEN} \text { at } \mathrm{IC}_{25-70} \\
\text { additive effects of } \mathrm{AFB}_{1}+\mathrm{DON} \text { at IC } \mathrm{IC}_{25-70} \\
\text { antagonism of } \mathrm{AFB}_{1}+\mathrm{ZEN} \text { at } \mathrm{IC}_{25-70} \\
\text { Cytotoxicity in RAW } 264.7: \\
\text { synergism of } \mathrm{AFB}_{1}+\mathrm{DON} \text { at IC } \mathrm{IC}_{25} ; \mathrm{DON}+\mathrm{ZEN}, \\
\mathrm{AFB}_{1}+\mathrm{DON}+\mathrm{ZEN} \text { at IC } \mathrm{IC}_{50,70} \\
\text { additive effects of } \mathrm{AFB}_{1}+\mathrm{DON} \text { at IC } \mathrm{I}_{50,70}, \mathrm{DON}+\mathrm{ZEN}, \\
\mathrm{AFB}_{1}+\mathrm{DON}+\mathrm{ZEN} \text { at } \mathrm{IC}_{25} \\
\text { antagonism of AFB1 }+\mathrm{ZEN} \text { at IC } \mathrm{IC}_{25-70}\end{array}$ & {$[60]$} \\
\hline
\end{tabular}


Table 2. Cont.

\begin{tabular}{|c|c|c|c|c|}
\hline $\begin{array}{l}\text { Mycotoxin } \\
\text { Combination }\end{array}$ & $\begin{array}{c}\text { In Vitro } \\
\text { Model }\end{array}$ & $\begin{array}{c}\text { Mathematical Model } \\
\text { Applied for the Endpoint }\end{array}$ & Endpoint Combined Effect & Reference \\
\hline $\begin{array}{c}\mathrm{AFM}_{1}+\text { OTA } \\
\mathrm{AFM}_{1}+\alpha-\mathrm{ZEL} \\
\mathrm{AFM}_{1}+\mathrm{ZEN} \\
\mathrm{OTA}+\mathrm{ZEN} \\
\mathrm{OTA}+\alpha-\mathrm{ZEL} \\
\mathrm{ZEN}+\alpha-\mathrm{ZEL} \\
\mathrm{AFM}_{1}+\mathrm{OTA}+\alpha-\mathrm{ZEL} \\
\mathrm{AFM}_{1}+\mathrm{ZEN}+\alpha-\mathrm{ZEL} \\
\mathrm{AFM}_{1}+\mathrm{OTA}+\mathrm{ZEN} \\
\mathrm{OTA}^{+} \mathrm{ZEN}+\alpha-\mathrm{ZEL} \\
\mathrm{AFM}_{1}+\mathrm{OTA}+\alpha-\mathrm{ZEL} \\
+\mathrm{ZEN}\end{array}$ & Caco-2 cells & $\begin{array}{c}\text { CI-Isobologram according to } \\
\text { Chou-Talalay method; CI at } \\
\mathrm{IC}_{25,50,75,90(1: 1,1: 1: 1 \text { and }} \text { 1:1:1.1) }\end{array}$ & 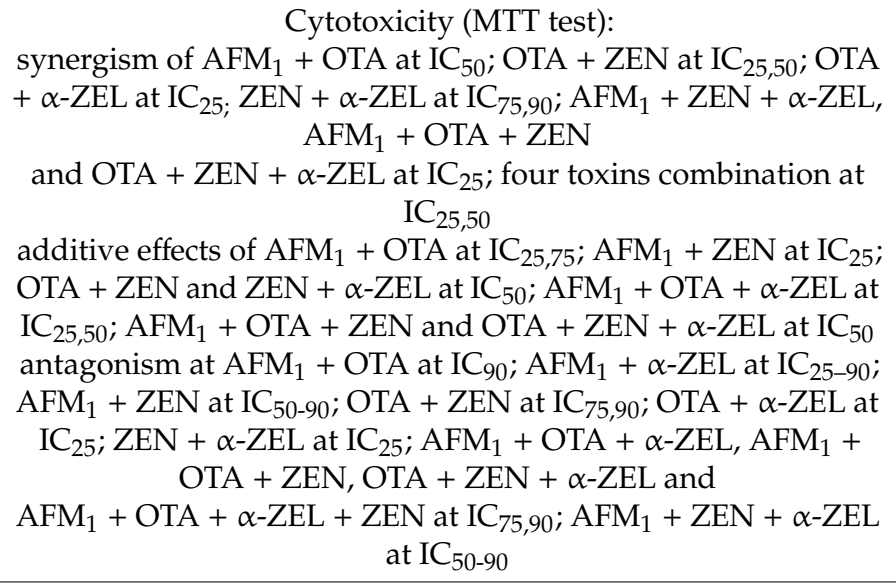 & {$[61]$} \\
\hline $\begin{array}{c}\text { ZEN }+\alpha-Z E L \\
Z \text { ZEN }+\beta-Z E L \\
\alpha-Z E L+\beta-Z E L\end{array}$ & HepG2 cells & $\begin{array}{l}\text { CI-Isobologram according to } \\
\text { Chou-Talalay method; CI at } \\
\qquad \mathrm{IL}_{25}-\mathrm{IL}_{75}(1: 1)\end{array}$ & 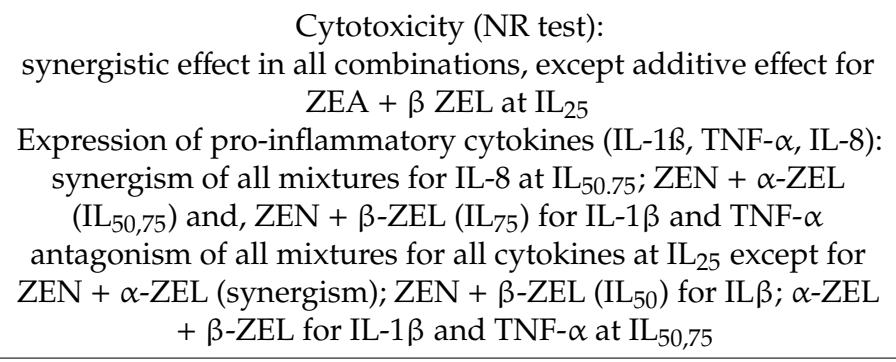 & {$[62]$} \\
\hline $\begin{array}{c}3-\mathrm{ADON}+\mathrm{AOH} \\
15-\mathrm{ADON}+\mathrm{AOH} \\
3-\mathrm{ADON}+15-\mathrm{ADON} \\
\mathrm{AOH}+3-\mathrm{ADON}+ \\
15-\mathrm{ADON}\end{array}$ & HepG2 cells & $\begin{array}{l}\text { CI-Isobologram according to } \\
\text { Chou-Talalay method; CI at } \\
\qquad \text { IC }_{25,50,75,90}(1: 1)\end{array}$ & $\begin{array}{l}\text { Cytotoxicity (MTT test) upon } 24,48 \text { and } 72 \mathrm{~h} \text { : } \\
\text { dominant synergism, 3-ADON }+\mathrm{AOH}\left(24 \text { and } 48 \mathrm{~h} \text { and } \mathrm{IC}_{25} 72\right. \\
\text { h), 15-ADON + AOH ( } 24 \mathrm{~h}), 3-\mathrm{ADON}+15-\mathrm{ADON} \text { and } \mathrm{AOH}+ \\
\text { 3-ADON + 15-ADON (all treatments) } \\
\text { additive effect of 3-ADON + AOH } \mathrm{IC}_{50-90}(72 \mathrm{~h}) ; 15-\mathrm{ADON}+ \\
\text { AOH at } \mathrm{IC}_{25,50}(48 \mathrm{~h}) \text { and } \mathrm{IC}_{50-90}(72 \mathrm{~h}) \\
\text { antagonism of } 15-\mathrm{ADON}+\mathrm{AOH} \text { at } \mathrm{IC}_{75,90}(48 \mathrm{~h}) \text { and } \mathrm{IC}_{25}(72 \mathrm{~h})\end{array}$ & {$[63]$} \\
\hline
\end{tabular}


Table 2. Cont.

\begin{tabular}{|c|c|c|c|c|}
\hline $\begin{array}{l}\text { Mycotoxin } \\
\text { Combination }\end{array}$ & $\begin{array}{c}\text { In Vitro } \\
\text { Model }\end{array}$ & $\begin{array}{l}\text { Mathematical Model } \\
\text { Applied for the Endpoint }\end{array}$ & Endpoint Combined Effect & Reference \\
\hline $\begin{array}{c}\mathrm{AFB}_{1}+\mathrm{DON} \\
\mathrm{AFB}_{1}+\mathrm{OTA} \\
\mathrm{DON}+\mathrm{OTA}\end{array}$ & Caco-2 and HepG2 cells & $\begin{array}{l}\text { CI-Isobologram according to } \\
\text { Chou-Talalay method; CI at } \\
\qquad \mathrm{IC}_{10}-\mathrm{IC}_{90}(1: 1)\end{array}$ & $\begin{array}{c}\text { Cytotoxicity (MTT test) in Caco-2 cells: } \\
\text { synergism of DON+OTA at IC } 10-\mathrm{IC}_{90} ; \mathrm{AFB}_{1}+\mathrm{DON} \text { at } \mathrm{IC}_{60-90} \\
\mathrm{AFB}_{1}+\mathrm{OTA} \text { at } \mathrm{IC}_{75-90} \\
\text { antagonism of AFB1 + OTA at } \mathrm{IC}_{10-50} ; \mathrm{AFB}_{1}+\mathrm{DON} \text { at } \mathrm{IC}_{10,30} \\
\text { Cytotoxicity in HepG2 cells: } \\
\text { synergism of } \mathrm{AFB}_{1}+\mathrm{DON} \text { at IC } \mathrm{IC}_{10-90} \\
\text { additive effects of } \mathrm{AFB}_{1}+\mathrm{OTA} \text { at } \mathrm{IC}_{10,90} ; \mathrm{DON}+\mathrm{OTA} \text { at } \mathrm{IC}_{60,90} \\
\text { antagonism of DON }+\mathrm{OTA} \text { at } \mathrm{IC}_{10-50}\end{array}$ & [64] \\
\hline $\begin{array}{c}\mathrm{DON}+\mathrm{PAT} \\
\mathrm{DON}+\mathrm{T} 2 \\
\mathrm{PAT}+\mathrm{T} 2 \\
\mathrm{DON}+\mathrm{T} 2+\mathrm{PAT}\end{array}$ & HepG2 cells & $\begin{array}{l}\text { CI-Isobologram according to } \\
\text { Chou-Talalay method; CI at } \\
\qquad \mathrm{IC}_{10}-\mathrm{IC}_{90}(1: 1)\end{array}$ & $\begin{array}{c}\text { Cytotoxicity (MTT test) upon } 24,48 \text { and } 72 \mathrm{~h} \text { : } \\
\text { no synergism } \\
\text { dominant additive effect of DON + PAT; DON + T2 upon } 72 \mathrm{~h} \\
\text { and at } \mathrm{IC}_{75,90}(24 \mathrm{~h}) ; \mathrm{PAT}+\mathrm{T} 2 \text { upon } 72 \mathrm{~h} \text { and at } \mathrm{IC}_{10,50-90}(24 \mathrm{~h}) ; \\
\mathrm{DON}+\mathrm{T} 2+\mathrm{PAT} \text { upon } 72 \mathrm{~h} \text { and at } \mathrm{IC}_{50-90}(24 \mathrm{~h}) \text { and } \mathrm{IC}_{25-90} \\
(\quad 48 \mathrm{~h}) \\
\text { antagonism of DON }+\mathrm{T} 2 \text { upon } 48 \mathrm{~h} \text { and at } \mathrm{IC}_{10-50}(48 \mathrm{~h}) ; \mathrm{PAT}+ \\
\mathrm{T}-2 \text { upon } 48 \mathrm{~h} \text { and at } \mathrm{IC}_{25}(24 \mathrm{~h}) ; \mathrm{DON}+\mathrm{T} 2+\mathrm{PAT} \text { at } \mathrm{IC}_{10,25}(24 \\
\mathrm{h}) \text { and } \mathrm{IC}_{10}(48 \mathrm{~h})\end{array}$ & [65] \\
\hline $\begin{array}{l}\text { DON + NIV (1:0.6) } \\
\text { NIV + FX }(3: 1) \\
\text { DON + FX }(1: 0.2) \\
\text { DON + NIV + FX } \\
\quad(1: 0.6: 0.2)\end{array}$ & $\begin{array}{l}\text { Jurkat human } \\
\text { T cells }\end{array}$ & $\begin{array}{l}\text { CI-Isobologram according to } \\
\text { Chou-Talalay method; CI at } \\
\quad \mathrm{IC}_{10}, \mathrm{IC}_{20} \text { and } \mathrm{IC}_{30}\end{array}$ & $\begin{array}{c}\text { Cytotoxicity (MTT test): } \\
\text { DON + NIV additive effect }\left(\mathrm{IC}_{10}\right) \text { and antagonism }\left(\mathrm{IC}_{20,30}\right) \\
\mathrm{NIV}+\mathrm{FX} \text { synergism } \\
\text { DON + FX antagonism } \\
\text { DON + NIV + FX antagonism }\end{array}$ & [52] \\
\hline $\mathrm{DON}+\mathrm{NIV}$ & $\begin{array}{l}\text { Differentiated } \\
\text { three-dimensional porcine } \\
\text { jejunal explants }\end{array}$ & $\begin{array}{l}\text { CI-Isobologram according to } \\
\text { Chou-Talalay method; CI at } \\
\text { equimolar concentrations } \\
\text { (1:1) }\end{array}$ & $\begin{array}{l}\text { mRNA expression of cytokines: } \\
\text { synergism in activation of all the tested pro-inflammatory } \\
\text { genes (IL-1 } \alpha, \beta, \text { IL-8, IL-17A, IL-22) }\end{array}$ & [53] \\
\hline
\end{tabular}


Table 2. Cont.

\begin{tabular}{|c|c|c|c|c|}
\hline $\begin{array}{l}\text { Mycotoxin } \\
\text { Combination }\end{array}$ & $\begin{array}{l}\text { In Vitro } \\
\text { Model }\end{array}$ & $\begin{array}{c}\text { Mathematical Model } \\
\text { Applied for the Endpoint }\end{array}$ & Endpoint Combined Effect & Reference \\
\hline $\begin{array}{c}\mathrm{DON}+\mathrm{NIV} \\
\mathrm{DON}+\mathrm{FX} \\
\mathrm{NIV}+\mathrm{FX} \\
\mathrm{DON}+\mathrm{NIV}+\mathrm{FX}\end{array}$ & $\begin{array}{c}\text { Human alveolar } \\
\text { adenocarcinoma (A549) and } \\
\text { bronchial 16HBE14o- cells } \\
\text { primary human bronchial } \\
\text { (hAECB) and nasal (hAECN) } \\
\text { cells }\end{array}$ & $\begin{array}{l}\text { CI-Isobologram method } \\
\text { derived from the } \\
\text { median-effect according to } \\
\text { Chou at } \mathrm{IC}_{10,30,50}(1: 1)\end{array}$ & 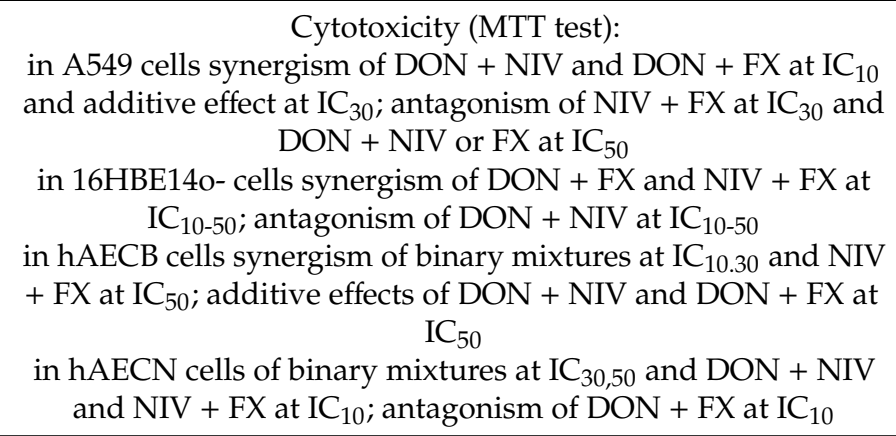 & [54] \\
\hline $\begin{array}{l}\text { DON + ZEN }(1: 7.5) \\
\text { NIV + T-2 }(1: 0.067) \\
\quad\left(\text { ratio of } \mathrm{IC}_{50}\right)\end{array}$ & HepaRG cells & $\begin{array}{l}\text { CI-Isobologram according to } \\
\text { Chou-Talalay method }\end{array}$ & $\begin{array}{c}\text { Cytotoxicity (MTS): } \\
\text { synergism of DON + ZEN at all applied concentrations } \\
\text { - synergism of NIV + T-2 at low concentrations } \\
\text { antagonism of NIV + T-2 at medium concentrations }\end{array}$ & [39] \\
\hline $\begin{array}{l}\mathrm{AFB}_{1}+\mathrm{DON}(1: 1.44) \\
\mathrm{AFB}_{1}+\mathrm{ZEN}(1: 15.19) \\
\mathrm{DON}+\mathrm{ZEN}(1: 10.56) \\
\mathrm{AFB}_{1}+\mathrm{DON}+\mathrm{ZEN} \\
\quad(1: 1.44: 15.19)\end{array}$ & $\begin{array}{l}\text { Fibroblast cell line BF-2 from } \\
\text { the caudal fin of Lepomis } \\
\text { macrochirus }\end{array}$ & $\begin{array}{l}\text { CI-Isobologram according to } \\
\text { Chou-Talalay method; CI at } \\
\qquad \mathrm{IC}_{10}-\mathrm{IC}_{50}\end{array}$ & $\begin{array}{c}\text { Cytotoxicity (resazurin): } \\
\text { synergism of } \mathrm{AFB}_{1}+\mathrm{DON} \text { and } \mathrm{AFB}_{1}+\mathrm{ZEN} \text { and ternary } \\
\text { mixture at } \mathrm{IC}_{10-30} \\
\text { additive effect of ternary mixture at } \mathrm{IC}_{40} \\
\text { antagonism of DON }+ \text { ZEN and ternary mixture at } \mathrm{IC}_{50}\end{array}$ & [55] \\
\hline $\begin{array}{l}\text { BEA + STC (1:5) } \\
\text { BEA + PAT }(3.2: 1) \\
\text { PAT + STC + (1:5) } \\
\text { BEA + PAT + STC } \\
\quad(3.2: 1: 5)\end{array}$ & $\begin{array}{l}\text { Chinese hamster ovary } \\
\text { CHO-K1 cells }\end{array}$ & $\begin{array}{l}\text { CI-Isobologram according to } \\
\text { Chou-Talalay method; CI at } \\
\qquad \mathrm{IC}_{5}-\mathrm{IC}_{50}\end{array}$ & 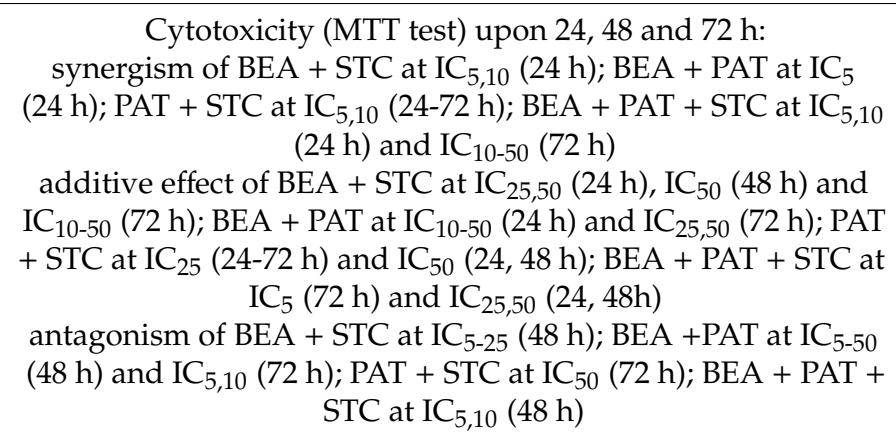 & [56] \\
\hline
\end{tabular}


Table 2. Cont.

\begin{tabular}{|c|c|c|c|c|}
\hline $\begin{array}{l}\text { Mycotoxin } \\
\text { Combination }\end{array}$ & $\begin{array}{c}\text { In Vitro } \\
\text { Model }\end{array}$ & $\begin{array}{l}\text { Mathematical Model } \\
\text { Applied for the Endpoint }\end{array}$ & Endpoint Combined Effect & Reference \\
\hline BEA + OTA & HepG2 cells & $\begin{array}{c}\text { CI-Isobologram according to } \\
\text { Chou-Talalay method; CI at } \\
\mathrm{IC}_{25}-\mathrm{IC}_{90}(1: 1) \text { and } \\
\text { equimolar ration }(1: 10)\end{array}$ & $\begin{array}{c}\text { Cytotoxicity (MTT test) upon } 24,48 \text { and } 72 \mathrm{~h} \text { : } \\
\text { synergism upon } 72 \mathrm{~h} \text { at } \mathrm{IC}_{25}-\mathrm{IC}_{90} ; 48 \mathrm{~h} \text { at } \mathrm{IC}_{25}-\mathrm{IC}_{75} ; \text { and } 1: 10 \\
\text { upon } 48 \text { and } 72 \mathrm{~h} \\
\text { additive effects upon } 24 \mathrm{~h} \text { at } \mathrm{IC}_{25}-\mathrm{IC}_{90} ; 48 \mathrm{~h} \text { at } \mathrm{IC}_{90} ; \text { and } 1: 10 \\
\text { upon } 24 \mathrm{~h}\end{array}$ & [57] \\
\hline $\begin{array}{c}\mathrm{CIT}+\mathrm{STC} \\
\mathrm{CIT}+\mathrm{M}-\mathrm{STC}\end{array}$ & $\begin{array}{l}\text { Human adenocarcinoma lung } \\
\text { A549 cells }\end{array}$ & $\begin{array}{l}\text { CI-Isobologram with } \\
\text { correction for unparalleled } \\
\text { dose-response curves, } \\
\text { developed by Anastasiadi et } \\
\text { al. [50]; "ray" desing with } \\
\text { 1:1, } 1: 2 \text { and 2:1 concentration } \\
\text { ratios }\end{array}$ & $\begin{array}{c}\text { Cytotoxicity (MTT test) } \\
\text { additive effect } \\
\text { antagonism exceptionally in low affected areas for CIT + } \\
\text { 5-MSTC and 2:1 CIT + STC, also between } \text { IC }_{25} \text { and } \text { IC }_{50} \text { for CIT } \\
+ \text { STC }\end{array}$ & $\begin{array}{l}\text { Personal } \\
\text { unpublished } \\
\text { data shown } \\
\text { in Figure } 2 .\end{array}$ \\
\hline $\mathrm{DON}+\mathrm{T} 2$ & $\begin{array}{l}\text { Human C-28/I2 and newborn } \\
\text { rat primary costal } \\
\text { chondrocytes (RC) }\end{array}$ & $\begin{array}{l}\text { MixLow method; } \\
\text { combination ratios of } \mathrm{DON} \\
\text { and T-2 toxin }(\mathrm{R} 1=1: 1 \mathrm{R} 10= \\
\text { 10:1, R100=100:1 and } \\
\text { R1000=1000:1). }\end{array}$ & $\begin{array}{c}\text { Cytotoxicity (MTT test): } \\
\text { synergism at fraction affected } 0.5,0.75,0.9 \text { of R10 concentrations } \\
\text { in RC } \\
\text { antagonism at fraction affected } 0.25 \text { of R100 in both cell types; } \\
\text { fraction affected } 0.5 \text { of R100 in C-28/12; fraction } 0.5 \text { of R1000 in } \\
\text { RC }\end{array}$ & {$[67]$} \\
\hline
\end{tabular}

$\mathrm{AFB}_{1}$ and $\mathrm{AFM}_{1}$ : aflatoxin $\mathrm{B}_{1}$ and $\mathrm{M}_{1}$, DON: deoxynivalenol, ZEN: zearalenone, OTA: ochratoxin $\mathrm{A}, \mathrm{FB}_{1}$ : fumonisn $\mathrm{B}_{1}$, PAT: patulin, BEA: beauvericin, CIT: citrinin, MPA: mycophenolic acid, PA: penicillic acid, 15-ADON: 15-acetyldeoxynivalenol, FX: fusarenon-X, NIV: nivalenol, AOH: alternariol, ATX II: altertoxin II, $\alpha$ and $\beta$-ZEL: $\alpha$ and $\beta$-Zearalenol, STC: sterigmatocystin, 5-M-STC: 5-Methoxysterigmatocystin; IC $10-90$ : inhibitory concentration 10-90\%, CI: combination index, AIP: alkaline phosphatase, MTT: (3-(4,5-dimethylthiazol-2-yl)-2,5-diphenyltetrazolium bromide) tetrazolium, OD: optical density, SRB: sulforhodamine B assay, NR: neutral red assay. 


\subsection{MixLow Method}

Compared to the Chou-Talalay method, the MixLow method (Table 2) used by Lin et al. [67] improves model fitting and removes bias by fitting the log-logistic curve without prior linearization, similarly to the CISNE method (discussed in Section 2.10). However, another improvement of the MixLow method is the inclusion of random effects in a model that can account for different batches (trays) in the experiment and fit the model for both toxins and combination simultaneously [31]. Mixed modelling enables a more precise estimation of the combination index's (CI, here called Loewe's index) and more reliable confidence intervals or standard errors by accounting for both the error of single applied mycotoxins and combinations.

The MixLow method comes with the mixlow R package, which also includes functions for straigthforward data import and minimal data preprocessing, especially if the pattern suggested on the tray is followed during experimental design [68].

\subsection{CISNE (Code for the Identification of Synergism Numerically Efficient)}

Even though Chou-Talalay's method exceeded two and a half thousand citations in relevant article databases, it does possess some technical problems in model fitting leading to bias inclusion in parameter estimation. By Chou-Talalay's protocol Equation (17) is rearranged and transformed to linear form (Equation (18)):

$$
\log [E /(1-E)]=m \times \log (D)-m \times \log \left(D_{M}\right),
$$

where $y$ is $\log [E /(1-E)]$, the intercept is $-m \times \log \left(D_{M}\right)$, the slope is $m$, and $x$ is the $\log (D)$ of the linear equation form. Estimating slope and intercept by least squares fit, and calculating $D_{m}$ as presented by Equation (19):

$$
D_{M}=e^{-i n t e r c e p t / s l o p e ~}
$$

This leads to bias, along with the exclusion of data points with effects smaller than $0 \%$ or larger than $100 \%$ (i.e., stimulation) which could not be used in the logarithm on the left side of Equation (18). García-Fuente et al. [33] showed that these biases can lead to significant false positive or false negative errors, depending on the slope of the dose-response curve. They also found that fitting the same equation as a non-linear regression model estimates model parameters better and reduces the rate of false positives or negatives, especially when the slope $(\mathrm{m})$ deviates from 1 . This non-linear regression can be easily applied using the free CISNE software [69]. In contrast, it has not yet been applied in mycotoxicology combination testing.

\subsection{Other methods}

Most of the recent studies used mathematical modelling according to Bliss or/and Loewe (or some modified Loewe's method) for assessing the nature of the effect of combination of mycotoxins. However several in vitro studies assed mycotoxin combined effects comparing the effect of combination to the effect of single mycotoxin [70-72] or only to negative controls [73-76] without estimating the theoretical (expected) effect of the combination (Table 3). Conclusions based on those studies are unreliable because the question of the nature of interaction of combination has not even been asked in a scientific manner to get a clear and exact answer. For example, Smith et al. [75] did not define the nature DON + ZEN interaction in HepRG cells; since the cytotoxic effect of a single DON was similar to the effect of DON + ZEN, it was concluded that a combined effect could not be classified as antagonistic nor synergistic. Any conclusion about an antagonistic or synergistic effect should include the effect of ZEN too, since it is a part of the mycotoxin combination. 
Table 3. Interactions between mycotoxin combinations in vitro without applying a mathematical model.

\begin{tabular}{|c|c|c|c|c|}
\hline $\begin{array}{l}\text { Mycotoxin } \\
\text { Combination }\end{array}$ & $\begin{array}{c}\text { In Vitro } \\
\text { Model }\end{array}$ & $\begin{array}{c}\text { Statistical Analysis } \\
\text { Applied for the Endpoint }\end{array}$ & Endpoint Combined Effect & Reference \\
\hline $\mathrm{DON}+\mathrm{ZEN}$ & $\begin{array}{l}\text { Porcine splenic } \\
\text { lymphocytes }\end{array}$ & $\begin{array}{l}\text { ANOVA followed by the } \\
\text { Tukey post } \\
\text { hoc test }(p<0.05)\end{array}$ & $\begin{array}{l}\text { Antioxidant parameters (MDA, GSH, CAT, SOD, Gpx): synergism } \\
\text { Apoptotic rate: synergism } \\
\text { Expression of p53, Bcl-2, Bax, caspase-3, and caspase-8: synergism }\end{array}$ & {$[70]$} \\
\hline $\begin{array}{l}\text { DON }+ \text { ZEN } \\
\text { (at concentrations } \\
\text { corresponding to the } \\
\text { AED, TDI and ML) }\end{array}$ & HepaRG cells & Student's t-test $(p<0.05)$ & $\begin{array}{c}\text { Cytotoxicity (MTS test) upon } 14,28 \text { and } 42 \text { days: } \\
\text { at ML no antagonistic or synergistic effect } \\
\text { transferrin, albumin and claudin- } 1 \text { (qPCR): } \\
\text { Gene expression of CYP4F3B, CYP3A4, } / \text { EBP } \alpha \text { HNF } \alpha \text {, aldolase B, } \\
\text { at AED majority of genes were } \uparrow \uparrow \text { after } 14 \text { days and } \downarrow \downarrow \text { after } 28 \text { days } \\
\text { at TDI the gene expression upon } 14 \text { and } 28 \text { days were less different but } \\
\text { more } \uparrow \uparrow \text { after } 28 \text { days } \\
\text { at ML DON and DON+ZEA reduced the cell viability by more than } 90 \% \text {, } \\
\text { no sufficient amounts of RNA } \\
\text { DON + ZEN affected different genes than single DON and ZEA }\end{array}$ & {$[75]$} \\
\hline $\begin{array}{c}\text { DON + 3ADON (3:1) } \\
\text { DON + 15-ADON (3:1) } \\
\text { 3-ADON + 15-ADON } \\
(1: 1) \\
\text { DON + 3-ADON + } \\
\text { 15-ADON (3:1:1) } \\
\left.\text { (ratios of } \mathrm{IC}_{50}\right)\end{array}$ & HepG2 cells & $\begin{array}{l}\text { ANOVA followed by the } \\
\text { Tukey post } \\
\text { hoc test }(p \leq 0.05)\end{array}$ & $\begin{array}{c}\text { Oxidative stress (ROS and MDA): } \\
\text { binary mixtures significantly increased ROS vs. control and initial time } \\
\text { binary and tertiary mixtures increased MDA vs. control }(24,48 \text { and } 72 \mathrm{~h} \text { ) } \\
\text { Cell cycle distribution upon } 48 \mathrm{~h} \text { (flow cytometry): } \\
\text { DON }+3 \text {-ADON } \downarrow \text { G0/G1 and S, G0/G1 and S, G2/M phase } \uparrow \text { at lower and } \\
\downarrow \text { at higher concentrations in respect to control } \\
\text { DON }+15 \text {-ADON } \uparrow \mathrm{G} 0 / \mathrm{G} 1 \text { and G2/M at lower and } \downarrow \text { at higher } \\
\text { concentrations in respect to control } \\
\text { 3-ADON }+15 \text {-ADON } \downarrow \text { G0/G1 and S at all concentrations vs. control } \\
\text { tertiary combination } \downarrow \text { G0/G1, } \mathrm{S} \text { and G2/M vs. control } \\
\text { Micronuclei (MN): } \\
\text { binary mixtures } \uparrow \text { in MN at lower concentrations vs. control } \\
\text { tertiary mixtures } \uparrow \text { in MN at all concentrations vs. control }\end{array}$ & {$[73,74]$} \\
\hline
\end{tabular}


Table 3. Cont.

\begin{tabular}{|c|c|c|c|c|}
\hline $\begin{array}{l}\text { Mycotoxin } \\
\text { Combination }\end{array}$ & $\begin{array}{c}\text { In Vitro } \\
\text { Model }\end{array}$ & $\begin{array}{c}\text { Statistical Analysis } \\
\text { Applied for the Endpoint }\end{array}$ & Endpoint Combined Effect & Reference \\
\hline $\begin{array}{c}\text { ENN } \mathrm{A}+\mathrm{A}_{1}+\mathrm{B}+\mathrm{B}_{1} \\
(1.5 \text { or } 3 \mu \mathrm{M}) \\
\text { ENN } \mathrm{A}+\mathrm{A}_{1}+\mathrm{B}+\mathrm{B}_{1} \\
+ \text { DON }(1.5 \text { or } 3 \mu \mathrm{M}) \\
\text { BEA }(2.5 \mu \mathrm{M})+\mathrm{DON} \\
(1.5 \text { or } 3 \mu \mathrm{M}) \\
\text { Apicidin }(0.438 \mu \mathrm{M})+ \\
\text { DON }(1.5 \text { or } 3 \mu \mathrm{M}) \\
\text { AURO }(5 \mu \mathrm{M})+\mathrm{DON} \\
(1.5 \text { or } 3 \mu \mathrm{M})\end{array}$ & $\begin{array}{l}\text { Porcine epithelial cells } \\
\text { IPEC-J2 }\end{array}$ & $\begin{array}{l}\text { ANOVA followed by the } \\
\text { Dunnett's t-test or } \\
\text { Kruskall-Wallis test } \\
\quad(p<0.05)\end{array}$ & $\begin{array}{c}\text { TEER upon } 24,48 \text { and } 72 \mathrm{~h} \text { : } \\
\text { dominant additive effect } \\
\text { DON had no effect on enniatin-induced TEER decrease } \\
\text { BEA + DON did not significantly reduce TEER }\end{array}$ & [76] \\
\hline $\mathrm{OTA}+\mathrm{CIT}$ & $\begin{array}{l}\text { Multiple organ } \\
\text { co-culture (IdMOC) of } \\
\text { HepG2 and 3T3 cells }\end{array}$ & $\begin{array}{l}\text { Paired sample } t \text {-test } \\
\qquad(p<0.05)\end{array}$ & $\begin{array}{c}\text { Luciferin-IPA metabolism assay: } \\
\text { synergism at } 20 \% \text { IC } 50 \text { (CTN forms a reactive } \\
\text { metabolite that diffuses out of HepG2 to cause cytotoxicity to } 3 \mathrm{~T} 3 \text { cells } \\
\text { synergistically with OTA) }\end{array}$ & {$[71]$} \\
\hline $\begin{array}{l}\text { OTA + CIT } \\
\text { (equimolar } \\
\text { concentrations } \\
0-30 \mu \mathrm{M})\end{array}$ & $\begin{array}{l}\text { Human embryonic } \\
\text { kidney HEK293 cells }\end{array}$ & $\begin{array}{l}\text { No statistical analysis } \\
\text { indicated/ } \\
\text { effect of combination was } \\
\text { compared to the effects of } \\
\text { mycotoxins acting alone }\end{array}$ & $\begin{array}{c}\text { Cytotoxicity (MTT test): } \\
\text { synergism based on IC } 50 \text { of single OTA }(16 \mu \mathrm{M}) \text { and CIT }(189 \mu \mathrm{M}) \text { vs. } \\
\text { combination }(7 \mu \mathrm{M})\end{array}$ & {$[72]$} \\
\hline
\end{tabular}




\section{Conclusions}

Some of the methods found in studies assessing the effects of mycotoxins combination have been incorrectly based on the assumption that mycotoxin dose-effect curves are linear (simple addition of effects, factorial analysis of variance). For that reason, many conclusions have been derived incorrectly in published articles or review articles based on published data. There are many articles reviewing methods and discussing the problem of the misuse of some method, but it seems that the problem persists. The only appropriate approach to assess the nature of an interaction is to correctly estimate the dose-effect curves of each mycotoxin and combination and apply a well-defined model (based on Bliss or Loewe's theory) with respecting the model's assumptions and fitting the model by a direct estimation of all model parameters from a nonlinear least squares fitting. Results should be presented in a simple and clearly defined way (i.e., isobologram or combination index) with some of the most expected (mean) values accompanied by uncertainty bounds, where a $95 \%$ confidence interval should have priority over the standard error due to asymmetrical distributions.

Improvements to the presented methods are continuously being made but are not readily applied in the field of mycotoxicology.

Author Contributions: Conceptualization, D.K. and M.Š.K.; methodology, D.K.; investigation, D.K., D.J. and M.Š.K.; writing-original draft preparation, D.K., D.J. and M.Š.K. All authors have read and agreed to the published version of the manuscript.

Funding: This research was funded by Croatian Science Foundation, grant number IP-09-2014-5982.

Acknowledgments: The authors want to thank Makso Herman, MA for English language editing.

Conflicts of Interest: The authors declare no conflict of interest.

\section{References}

1. Pitt, J.I.; David Miller, J. A Concise History of Mycotoxin Research. J. Agric. Food Chem. 2017, 65, 7021-7033. [CrossRef] [PubMed]

2. Venkatesh, N.; Keller, N.P. Mycotoxins in conversation with bacteria and fungi. Front. Microbiol. 2019, 10, 403. [CrossRef]

3. Fox, E.M.; Howlett, B.J. Secondary metabolism: Regulation and role in fungal biology. Curr. Opin. Microbiol. 2008, 11, 481-487. [CrossRef]

4. Van Egmond, H.P.; Schothorst, R.C.; Jonker, M.A. Regulations relating to mycotoxins in food. Anal. Bioanal. Chem. 2007, 389, 147-157. [CrossRef] [PubMed]

5. Assunção, R.; Silva, M.J.; Alvito, P. Challenges in risk assessment of multiple mycotoxins in food. World Mycotoxin J. 2016, 9, 791-811. [CrossRef]

6. Abdallah, M.F.; Girgin, G.; Baydar, T.; Krska, R.; Sulyok, M. Occurrence of multiple mycotoxins and other fungal metabolites in animal feed and maize samples from Egypt using LC-MS/MS. J. Sci. Food Agric. 2017, 97, 4419-4428. [CrossRef] [PubMed]

7. Malachová, A.; Sulyok, M.; Beltrán, E.; Berthiller, F.; Krska, R. Optimization and validation of a quantitative liquid chromatography-tandem mass spectrometric method covering 295 bacterial and fungal metabolites including all regulated mycotoxins in four model food matrices. J. Chromatogr. A 2014, 1362, 145-156. [CrossRef]

8. Gruber-Dorninger, C.; Novak, B.; Nagl, V.; Berthiller, F. Emerging Mycotoxins: Beyond Traditionally Determined Food Contaminants. J. Agric. Food Chem. 2017, 65, 7052-7070. [CrossRef]

9. Kovač, M.; Šubarić, D.; Bulaić, M.; Kovač, T.; Šarkanj, B. Yesterday masked, today modified; what do mycotoxins bring next? Arh. Hig. Rada Toksikol. 2018, 69, 196-214. [CrossRef]

10. Ibáñez-Vea, M.; González-Peñas, E.; Lizarraga, E.; López de Cerain, A. Co-occurrence of aflatoxins, ochratoxin A and zearalenone in barley from a northern region of Spain. Food Chem. 2012, 132, 35-42. [CrossRef]

11. Santini, A.; Meca, G.; Uhlig, S.; Ritieni, A. Fusaproliferin, beauvericin and enniatins: Occurrence in food-A review. World Mycotoxin J. 2012, 5, 71-81. [CrossRef] 
12. Streit, E.; Schatzmayr, G.; Tassis, P.; Tzika, E.; Marin, D.; Taranu, I.; Tabuc, C.; Nicolau, A.; Aprodu, I.; Puel, O.; et al. Current situation of mycotoxin contamination and co-occurrence in animal feed focus on Europe. Toxins 2012, 4, 788-809. [CrossRef] [PubMed]

13. Vaclavikova, M.; Malachova, A.; Veprikova, Z.; Dzuman, Z.; Zachariasova, M.; Hajslova, J. "Emerging” mycotoxins in cereals processing chains: Changes of enniatins during beer and bread making. Food Chem. 2013, 136, 750-757. [CrossRef]

14. Kademi, H.I.; Baba, I.A.; Saad, F.T. Modelling the dynamics of toxicity associated with aflatoxins in foods and feeds. Toxicol. Rep. 2017, 4, 358-363. [CrossRef] [PubMed]

15. Garcia, D.; Ramos, A.J.; Sanchis, V.; Marín, S. Predicting mycotoxins in foods: A review. Food Microbiol. 2009, 26, 757-769. [CrossRef] [PubMed]

16. Lee, S.; Yoon, Y.; Kim, D.M.; Kim, D.S.; Park, K.H.; Chun, H.S. Mathematical models to predict kinetic behavior and aflatoxin production of Aspergillus flavus under various temperature and water activity conditions. Food Sci. Biotechnol. 2014, 23, 975-982. [CrossRef]

17. Smith, M.C.; Madec, S.; Coton, E.; Hymery, N. Natural Co-occurrence of mycotoxins in foods and feeds and their in vitro combined toxicological effects. Toxins 2016, 8, 94. [CrossRef]

18. Alassane-Kpembi, I.; Schatzmayr, G.; Taranu, I.; Marin, D.; Puel, O.; Oswald, I.P. Mycotoxins co-contamination: Methodological aspects and biological relevance of combined toxicity studies. Crit. Rev. Food Sci. Nutr. 2017, 57, 3489-3507. [CrossRef]

19. Grenier, B.; Oswald, I. Mycotoxin co-contamination of food and feed: Meta-analysis of publications describing toxicological interactions. World Mycotoxin J. 2011, 4, 285-313. [CrossRef]

20. Šegvić Klarić, M. Adverse effects of combined mycotoxins. Arh. Hig. Rada Toksikol. 2012, 63, 519-530. [CrossRef]

21. Šegvić Klarić, M.; Rašić, D.; Peraica, M. Deleterious effects of mycotoxin combinations involving ochratoxin A. Toxins 2013, 5, 1965-1987.

22. Tekin, E.; Beppler, C.; White, C.; Mao, Z.; Savage, V.M.; Yeh, P.J. Enhanced identification of synergistic and antagonistic emergent interactions among three or more drugs. J. R. Soc. Interface 2016, 13, 18-20. [CrossRef] [PubMed]

23. Foucquier, J.; Guedj, M. Analysis of drug combinations: Current methodological landscape. Pharmacol. Res. Perspect. 2015, 3. [CrossRef] [PubMed]

24. Weber, F.; Freudinger, R.; Schwerdt, G.; Gekle, M. A rapid screening method to test apoptotic synergisms of ochratoxin A with other nephrotoxic substances. Toxicol. Vitr. 2005, 19, 135-143. [CrossRef] [PubMed]

25. Caudle, R.M.; Williams, G.M. The misuse of analysis of variance to detect synergy in combination drug studies. Pain 1993, 55, 313-317. [CrossRef]

26. Bliss, C.I. The toxicity of poisons applied jointly. Ann. Appl. Biol. 1939, 26, 585-615. [CrossRef]

27. Loewe, S.; Muischnek, H. Über Kombinationswirkungen. Arch. Für Exp. Pathol. Und Pharmakologie 1926, 114, 313-326. [CrossRef]

28. Jonker, M.J.; Svendsen, C.; Bedaux, J.J.M.; Bongers, M.; Kammenga, J.E. Significance testing of synergistic/antagonistic, dose level-dependent, or dose ratio-dependent effects in mixture dose-response analysis. Environ. Toxicol. Chem. 2005, 24, 2701. [CrossRef]

29. Berenbaum, M.C. Criteria for analyzing interactions between biologically active agents. Adv. Cancer Res. 1981, 35, 269-335.

30. Chou, T.-C. Theoretical basis, experimental design, and computerized simulation of synergism and antagonism in drug combination studies. Pharmacol. Rev. 2006, 58, 621-681. [CrossRef]

31. Boik, J.C.; Newman, R.A.; Boik, R.J. Quantifying synergism/antagonism using nonlinear mixed-effects modeling: A simulation study. Stat. Med. 2008, 27, 1040-1061. [CrossRef] [PubMed]

32. Berenbaum, M.C. What is synergy? Pharmacol. Rev. 1989, 41, 93-141.

33. García-Fuente, A.; Vázquez, F.; Viéitez, J.M.; García Alonso, F.J.; Martín, J.I.; Ferrer, J. CISNE: An accurate description of dose-effect and synergism in combination therapies. Sci. Rep. 2018, 8, 1-9. [CrossRef] [PubMed]

34. Šegvić Klarić, M.; Daraboš, D.; Rozgaj, R.; Kašuba, V.; Pepeljnjak, S. Beauvericin and ochratoxin A genotoxicity evaluated using the alkaline comet assay: Single and combined genotoxic action. Arch. Toxicol. 2010, 84, 641-650. [CrossRef] 
35. Huang, X.; Gao, Y.; Li, S.; Wu, C.; Wang, J.; Zheng, N. Modulation of Mucin (MUC2, MUC5AC AND MUC5B) mRNA expression and protein production and secretion in Caco-2/HT29-MTX co-cultures following exposure to individual and combined aflatoxin M1 and ochratoxin A. Toxins 2019, 11, 132. [CrossRef] [PubMed]

36. Du, M.; Liu, Y.; Zhang, G. Interaction of aflatoxin B1 and fumonisin B1 in HepG2 cell apoptosis. Food Biosci. 2017, 20, 131-140. [CrossRef]

37. Zheng, N.; Gao, Y.N.; Liu, J.; Wang, H.W.; Wang, J.Q. Individual and combined cytotoxicity assessment of zearalenone with ochratoxin A or $\alpha$-zearalenol by full factorial design. Food Sci. Biotechnol. 2018, 27, 251-259. [CrossRef]

38. Smith, M.-C.; Gheux, A.; Coton, M.; Madec, S.; Hymery, N.; Coton, E. In vitro co-culture models to evaluate acute cytotoxicity of individual and combined mycotoxin exposures on Caco-2, THP-1 and HepaRG human cell lines. Chem. Biol. Interact. 2018, 281, 51-59. [CrossRef]

39. Smith, M.C.; Hymery, N.; Troadec, S.; Pawtowski, A.; Coton, E.; Madec, S. Hepatotoxicity of fusariotoxins, alone and in combination, towards the HepaRG human hepatocyte cell line. Food Chem. Toxicol. 2017, 109, 439-451. [CrossRef]

40. Li, Y.; Wang, T.Q.; Wu, J.; Zhang, X.L.; Xu, Y.Y.; Qian, Y.Z. Multi-parameter analysis of combined hepatotoxicity induced by mycotoxin mixtures in HepG2 cells. World Mycotoxin J. 2018, 11, 225-235. [CrossRef]

41. Vejdovszky, K.; Warth, B.; Sulyok, M.; Marko, D. Non-synergistic cytotoxic effects of Fusarium and Alternaria toxin combinations in Caco-2 cells. Toxicol. Lett. 2016, 241, 1-8. [CrossRef] [PubMed]

42. Tallarida, R.J. Quantitative methods for assessing drug synergism. Genes Cancer 2011, 2, 1003-1008. [CrossRef] [PubMed]

43. Geary, N. Understanding synergy. Am. J. Physiol. Metab. 2013, 304, E237-E253. [CrossRef] [PubMed]

44. Li, Y.; Zhang, B.; He, X.; Cheng, W.H.; Xu, W.; Luo, Y.; Liang, R.; Luo, H.; Huang, K. Analysis of individual and combined effects of ochratoxin a and zearalenone on HepG2 and KK-1 cells with mathematical models. Toxins 2014, 6, 1177-1192. [CrossRef] [PubMed]

45. Oh, S.Y.; Cedergreen, N.; Yiannikouris, A.; Swamy, H.V.L.N.; Karrow, N.A. Assessing interactions of binary mixtures of Penicillium mycotoxins (PMs) by using a bovine macrophage cell line (BoMacs). Toxicol. Appl. Pharmacol. 2017, 318, 33-40. [CrossRef] [PubMed]

46. Assunção, R.; Pinhão, M.; Loureiro, S.; Alvito, P.; Silva, M.J. A multi-endpoint approach to the combined toxic effects of patulin and ochratoxin a in human intestinal cells. Toxicol. Lett. 2019, 313, 120-129. [CrossRef]

47. Vejdovszky, K.; Sack, M.; Jarolim, K.; Aichinger, G.; Somoza, M.M.; Marko, D. In vitro combinatory effects of the Alternaria mycotoxins alternariol and altertoxin II and potentially involved miRNAs. Toxicol. Lett. 2017, 267, 45-52. [CrossRef]

48. Solhaug, A.; Karlsøen, L.M.; Holme, J.A.; Kristoffersen, A.B.; Eriksen, G.S. Immunomodulatory effects of individual and combined mycotoxins in the THP-1 cell line. Toxicol. Vitr. 2016, 36, 120-132. [CrossRef]

49. Tallarida, R.J. Revisiting the isobole and related quantitative methods for assessing drug synergism. J. Pharmacol. Exp. Ther. 2012, 342, 2-8. [CrossRef]

50. Anastasiadi, M.; Polizzi, K.; Lambert, R.J.W. An improved model for the analysis of combined antimicrobials: A replacement for the Chou-Talalay combination index method. J. Appl. Microbiol. 2018, 124, 97-107. [CrossRef]

51. Vejdovszky, K.; Hahn, K.; Braun, D.; Warth, B.; Marko, D. Synergistic estrogenic effects of Fusarium and Alternaria mycotoxins in vitro. Arch. Toxicol. 2017, 91, 1447-1460. [CrossRef] [PubMed]

52. Aupanun, S.; Phuektes, P.; Poapolathep, S.; Alassane-Kpembi, I.; Oswald, I.P.; Poapolathep, A. Individual and combined cytotoxicity of major trichothecenes type $\mathrm{B}$, deoxynivalenol, nivalenol, and fusarenon- $\mathrm{X}$ on Jurkat human T cells. Toxicon 2019, 160, 29-37. [CrossRef] [PubMed]

53. Alassane-Kpembi, I.; Puel, O.; Pinton, P.; Cossalter, A.M.; Chou, T.C.; Oswald, I.P. Co-exposure to low doses of the food contaminants deoxynivalenol and nivalenol has a synergistic inflammatory effect on intestinal explants. Arch. Toxicol. 2017, 91, 2677-2687. [CrossRef] [PubMed]

54. Ferreira Lopes, S.; Vacher, G.; Ciarlo, E.; Savova-Bianchi, D.; Roger, T.; Niculita-Hirzel, H. Primary and Immortalized Human Respiratory Cells Display Different Patterns of Cytotoxicity and Cytokine Release upon Exposure to Deoxynivalenol, Nivalenol and Fusarenon-X. Toxins 2017, 9, 337. [CrossRef]

55. Zhou, H.; George, S.; Li, C.; Gurusamy, S.; Sun, X.; Gong, Z.; Qian, H. Combined toxicity of prevalent mycotoxins studied in fish cell line and zebrafish larvae revealed that type of interactions is dose-dependent. Aquat. Toxicol. 2017, 193, 60-71. [CrossRef] 
56. Zouaoui, N.; Mallebrera, B.; Berrada, H.; Abid-Essefi, S.; Bacha, H.; Ruiz, M.J. Cytotoxic effects induced by patulin, sterigmatocystin and beauvericin on CHO-K1 cells. Food Chem. Toxicol. 2016, 89, 92-103. [CrossRef]

57. Juan-García, A.; Tolosa, J.; Juan, C.; Ruiz, M.-J. Cytotoxicity, genotoxicity and disturbance of cell cycle in HepG2 Cells exposed to OTA and BEA: Single and combined actions. Toxins 2019, 11, 341. [CrossRef]

58. Lei, Y.; Guanghui, Z.; Xi, W.; Yingting, W.; Xialu, L.; Fangfang, Y.; Goldring, M.B.; Xiong, G.; Lammi, M.J. Cellular responses to T-2 toxin and/or deoxynivalenol that induce cartilage damage are not specific to chondrocytes. Sci. Rep. 2017, 7, 1-14. [CrossRef]

59. Yang, Y.; Yu, S.; Tan, Y.; Liu, N.; Wu, A. Individual and combined cytotoxic effects of co-occurring deoxynivalenol family mycotoxins on human gastric epithelial cells. Toxins 2017, 9, 96. [CrossRef]

60. Zhou, H.; George, S.; Hay, C.; Lee, J.; Qian, H.; Sun, X. Individual and combined effects of aflatoxin B1, deoxynivalenol and zearalenone on HepG2 and RAW 264.7 cell lines. Food Chem. Toxicol. 2017, 103, 18-27. [CrossRef]

61. Gao, Y.N.; Wang, J.Q.; Li, S.L.; Zhang, Y.D.; Zheng, N. Aflatoxin M1 cytotoxicity against human intestinal Caco-2 cells is enhanced in the presence of other mycotoxins. Food Chem. Toxicol. 2016, 96, 79-89. [CrossRef] [PubMed]

62. Marin, D.E.; Pistol, G.C.; Bulgaru, C.V.; Taranu, I. Cytotoxic and inflammatory effects of individual and combined exposure of HepG2 cells to zearalenone and its metabolites. Naunyn. Schmiedebergs. Arch. Pharmacol. 2019, 392, 937-947. [CrossRef] [PubMed]

63. Juan-García, A.; Juan, C.; Manyes, L.; Ruiz, M.J. Binary and tertiary combination of alternariol, 3-acetyl-deoxynivalenol and 15-acetyl-deoxynivalenol on HepG2 cells: Toxic effects and evaluation of degradation products. Toxicol. Vitr. 2016, 34, 264-273. [CrossRef]

64. Sobral, M.M.C.; Faria, M.A.; Cunha, S.C.; Ferreira, I.M.P.L.V.O. Toxicological interactions between mycotoxins from ubiquitous fungi: Impact on hepatic and intestinal human epithelial cells. Chemosphere 2018, 202, 538-548. [CrossRef] [PubMed]

65. Fernández-Blanco, C.; Elmo, L.; Waldner, T.; Ruiz, M.J. Cytotoxic effects induced by patulin, deoxynivalenol and toxin T2 individually and in combination in hepatic cells (HepG2). Food Chem. Toxicol. 2018, 120, 12-23. [CrossRef] [PubMed]

66. Lee, J.J.; Kong, M. Confidence Intervals of Interaction Index for Assessing Multiple Drug Interaction. Stat. Biopharm. Res. 2009, 1, 4-17. [CrossRef] [PubMed]

67. Lin, X.; Shao, W.; Yu, F.; Xing, K.; Liu, H.; Zhang, F.; Goldring, M.B.; Lammi, M.J.; Guo, X. Individual and combined toxicity of T-2 toxin and deoxynivalenol on human C-28/I2 and rat primary chondrocytes. J. Appl. Toxicol. 2019, 39, 343-353. [CrossRef]

68. Boik, J.C.; Narasimhan, B. An R package for assessing drug synergism/antagonism. J. Stat. Softw. 2010, 34, 1-18. [CrossRef]

69. CISNE Code for the Identification of Synergism Numerically Efficient. Available online: https://cisnecode. github.io (accessed on 29 February 2020).

70. Ren, Z.; Deng, H.; Deng, Y.; Liang, Z.; Deng, J.; Zuo, Z.; Hu, Y.; Shen, L.; Yu, S.; Cao, S. Combined effects of deoxynivalenol and zearalenone on oxidative injury and apoptosis in porcine splenic lymphocytes in vitro. Exp. Toxicol. Pathol. 2017, 69, 612-617. [CrossRef]

71. Gayathri, L.; Karthikeyan, B.S.; Rajalakshmi, M.; Dhanasekaran, D.; Li, A.P.; Akbarsha, M.A. Metabolism-dependent cytotoxicity of citrinin and ochratoxin A alone and in combination as assessed adopting integrated discrete multiple organ co-culture (IdMOC). Toxicol. Vitr. 2018, 46, 166-177. [CrossRef]

72. Gong, L.; Zhu, H.; Li, T.; Ming, G.; Duan, X.; Wang, J.; Jiang, Y. Molecular signatures of cytotoxic effects in human embryonic kidney 293 cells treated with single and mixture of ochratoxin A and citrinin. Food Chem. Toxicol. 2019, 123, 374-384. [CrossRef] [PubMed]

73. Juan-García, A.; Juan, C.; Tolosa, J.; Ruiz, M.J. Effects of deoxynivalenol, 3-acetyl-deoxynivalenol and 15-acetyl-deoxynivalenol on parameters associated with oxidative stress in HepG2 cells. Mycotoxin Res. 2019, 35, 197-205. [CrossRef] [PubMed]

74. Juan-García, A.; Taroncher, M.; Font, G.; Ruiz, M.J. Micronucleus induction and cell cycle alterations produced by deoxynivalenol and its acetylated derivatives in individual and combined exposure on HepG2 cells. Food Chem. Toxicol. 2018, 118, 719-725. [CrossRef] [PubMed] 
75. Smith, M.C.; Madec, S.; Pawtowski, A.; Coton, E.; Hymery, N. Individual and combined toxicological effects of deoxynivalenol and zearalenone on human hepatocytes in in vitro chronic exposure conditions. Toxicol. Lett. 2017, 280, 238-246. [CrossRef]

76. Springler, A.; Vrubel, G.J.; Mayer, E.; Schatzmayr, G.; Novak, B. Effect of Fusarium-derived metabolites on the barrier integrity of differentiated intestinal porcine epithelial cells (IPEC-J2). Toxins 2016, 8, 345. [CrossRef] 